(W)

Check for

updates

Cite as

Nano-Micro Lett.

(2022) $14: 22$

Received: 22 July 2021

Accepted: 10 October 2021

Published online: 9 December 2021

(C) The Author(s) 2021

\section{A MXene-Based Bionic Cascaded-Enzyme Nanoreactor for Tumor Phototherapy/Enzyme Dynamic Therapy and Hypoxia-Activated Chemotherapy}

\author{
Xiaoge Zhang ${ }^{1}$, Lili Cheng ${ }^{1}$, Yao Lu ${ }^{1}$, Junjie Tang ${ }^{1}$, Qijun $\mathrm{Lv}^{2}$, Xiaomei Chen ${ }^{1}$, \\ You Chen ${ }^{1}$, Jie Liu ${ }^{1}$
}

\title{
HIGHLIGHTS
}

- Gene-engineering tumor cell membrane with CD47 over-expression is achieved to improve the macrophage-mediated phagocytosis of tumor cells by blocking CD47 immune checkpoint.

- A cascade-enzyme nanoreactor combining tumor enzyme dynamic therapy, phototherapy, and deoxygenation-activated chemotherapy is proposed.

- Glucose oxidase and chloroperoxidase can generate sufficient $\mathrm{HClO}$ to kill normoxic tumor cells, and tirapazamine can be subsequently activated to kill hypoxic tumor cells.

\begin{abstract}
The enzyme-mediated elevation of reactive oxygen species (ROS) at the tumor sites has become an emerging strategy for regulating intracellular redox status for anticancer treatment. Herein, we proposed a camouflaged bionic cascaded-enzyme nanoreactor based on $\mathrm{Ti}_{3} \mathrm{C}_{2}$ nanosheets for combined tumor enzyme dynamic therapy (EDT), phototherapy and deoxygenation-activated chemotherapy. Briefly, glucose oxidase (GOX) and chloroperoxidase (CPO) were chemically conjugated onto $\mathrm{Ti}_{3} \mathrm{C}_{2}$ nanosheets, where the deoxygenation-activated drug tirapazamine (TPZ) was also loaded, and the $\mathrm{Ti}_{3} \mathrm{C}_{2}$-GOX-CPO/TPZ (TGCT) was embedded into nanosized cancer cell-derived membrane vesicles with high-expressed CD47 ( $\mathrm{m}_{\mathrm{e}}$ TGCT). Due to biomimetic membrane camouflage and CD47 overexpression, $\mathrm{m}_{\mathrm{e}}$ TGCT exhibited superior immune escape and homologous targeting capacities, which could

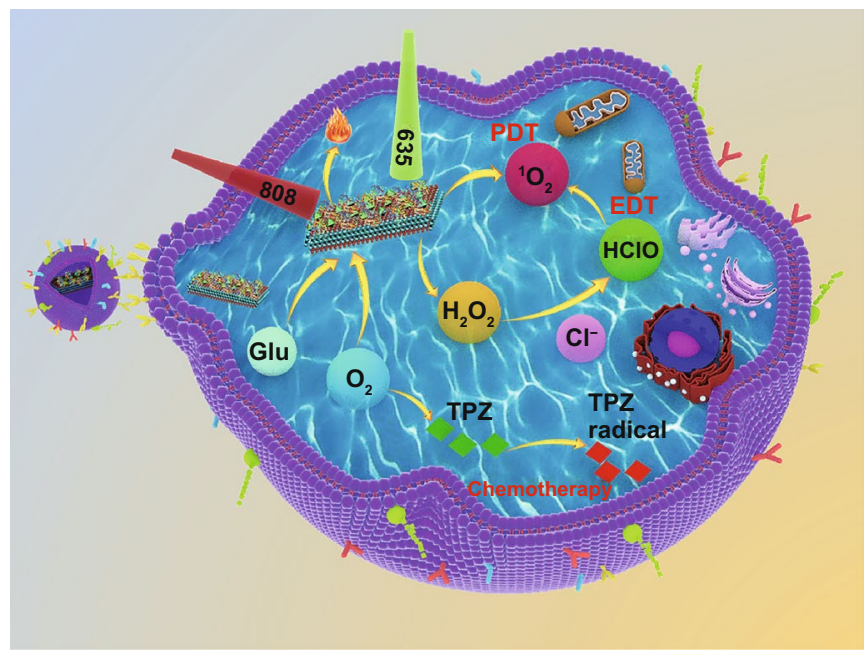
effectively enhance the tumor preferential targeting and internalization. Once internalized into tumor cells, the cascade reaction of GOX and $\mathrm{CPO}$ could generate $\mathrm{HClO}$ for efficient EDT. Simultaneously, additional laser irradiation could accelerate the enzymic-catalytic reaction rate and increase the generation of singlet oxygen $\left({ }^{1} \mathrm{O}_{2}\right)$. Furthermore, local hypoxia environment with the oxygen depletion by EDT

$\triangle$ Jie Liu, liujie56@mail.sysu.edu.cn

1 School of Biomedical Engineering, Shenzhen Campus of Sun Yat-Sen University, No. 66, Gongchang Road, Guangming District, Shenzhen, Guangdong 518107, People's Republic of China

2 Department of General Surgery, The Third Affiliated Hospital of Sun Yat-Sen University, Guangzhou, Guangdong 510006, People's Republic of China
\end{abstract}


would activate deoxygenation-sensitive prodrug for additional chemotherapy. Consequently, $\mathrm{m}_{\mathrm{e}}$ TGCT exhibits amplified synergistic therapeutic effects of tumor phototherapy, EDT and chemotherapy for efficient tumor inhibition. This intelligent cascaded-enzyme nanoreactor provides a promising approach to achieve concurrent and significant antitumor therapy.

KEYWORDS Cascaded-enzyme nanoreactor; Deoxygenation-sensitive prodrugs; Tumor enzyme dynamic therapy; Phototherapy; CD47

\section{Introduction}

Malignant tumors are still major diseases that threaten human health, and the number of cancer death has increased by nearly $20 \%$ in the past 10 years [1]. Among kinds of conventional clinical cancer therapies, chemotherapy is still widely used in clinic as the main treatment mean except for surgery, but the toxic side effects caused by drug resistance, high invasiveness and lack of specific targeting significantly limit its therapeutic effect [2-4]. Therefore, it is urgent to study advanced treatments of cancer. In most recent study, a new kind of strategy so called enzyme dynamic therapy (EDT) provided an innovative approach for tumor treatment by fully taking advantage of the enzyme-catalyzed reactions in tumor microenvironment (TME) to generate different kinds of cytotoxic reactive oxygen species (ROS) [5, 6]. Proverbially, ROS is responsible for regulating intracellular signaling pathways and redox environments [7-9]. The redox environment of tumor cells has better selectivity than normal cells, and rapid accumulation of ROS in a short time can break the vulnerable redox balance and increase the oxidative stress levels in the cells, eventually leading to cancer cell damage and death [10-13]. Therefore, the ROS elevation is considered as an effective way to improve the effect of tumor treatment .

Among the ROS family, highly reactive hypochlorous acid ( $\mathrm{HClO})$ is the strongest factor, which can be produced by chloroperoxidase (CPO) catalysis to increase intracellular oxidative stress level and irreversibly destroy proteins, nucleic acids, lipids and carbohydrates [14]. As a highly active peroxidase of calcium-rich yeast with strong antioxidant inactivation ability, CPO enzyme can catalyze the reaction of chlorine ion $\left(\mathrm{Cl}^{-}\right)$ and hydrogen peroxide $\left(\mathrm{H}_{2} \mathrm{O}_{2}\right)$ to generate $\mathrm{HClO}$ and the subsequent decomposition of $\mathrm{HClO}$ can produce singlet oxygen $\left({ }^{1} \mathrm{O}_{2}\right)$, forming the $\mathrm{CPO}-\mathrm{H}_{2} \mathrm{O}_{2}$-Halogen system for antitumor effect and killing microorganisms [15-17]. However, CPOmediated catalytic reaction alone is inefficient for $\mathrm{HClO}$ generation owing to the low level of $\mathrm{H}_{2} \mathrm{O}_{2}$ in the tumor region [18]. Therefore, it is necessary to elevate the level of $\mathrm{H}_{2} \mathrm{O}_{2}$ in the tumor region for the improvement of the $\mathrm{HClO}$-mediated antitumor effect. So far, various kinds of strategies have been designed to elevate the endogenous $\mathrm{H}_{2} \mathrm{O}_{2}$, such as glucose oxidase (GOX) biocatalysis, nicotinamide adenine dinucleotide phosphate (NADPH) oxidase biocatalysis and superoxide dismutase (SOD) biocatalysis [5, 17, 19]. There into, GOX has been applied repeatedly as an $\mathrm{H}_{2} \mathrm{O}_{2}$ generator for its particular enzyme activity of catalyzing glucose into abundant $\mathrm{H}_{2} \mathrm{O}_{2}$ and gluconic acid, and this process can also consume tumor cell energy to achieve tumor starvation and death [20-23].

In this work, GOX and CPO were designed as the cascaded-enzyme reactor to cut off the intratumoral glucose supply and generate sustained $\mathrm{HClO}$ for effective tumor starvation treatment and EDT without external energy. However, the $\mathrm{O}_{2}$ consumption in the tumor tissue during starvation treatment exacerbates the degree of hypoxia in the TME, which in turn limits the effectiveness of tumor treatment and induces tumor recurrence and metastasis [24, 25]. To kill the hypoxic tumor cell, tirapazamine (TPZ), as an deoxygenation-sensitive prodrug, can be converted to cytotoxic instantaneous intermediates (Benzotriazine, BTZ) that can induce double-stranded DNA rupture and the hypoxic cells death by topoisomerase II-dependence process [26, 27]. Therefore, the combination of the cascaded-enzyme and TPZ may achieve amplified antitumor therapeutic effects. Besides, to protect enzymes from protein structure degradation and deactivation and deliver multiple components with high drug loading for effectively EDT and chemotherapy simultaneously, twodimensional transition metal carbides/nitrides (2D MXenes) with good biocompatibility and high specific surface area [28, 29] were applied to co-load the cascaded-enzyme and drug to improve the accumulation in the tumor sites. In the meantime, 2D MXenes can transfer external energy for the generation of exogenous ROS to effectively cause tumor cell apoptosis under laser irradiation [30-32]. Therefore, a strategy of combining physical and biological enzymatic reactions for the enhanced antitumor effect is constructed, for which the laser irradiation can provide short-term exogenous ROS and the enzyme can provide sustainable endogenous ROS.

Herein, we designed and proposed a camouflaged nanocascaded catalytic system by combining tumor enzyme 


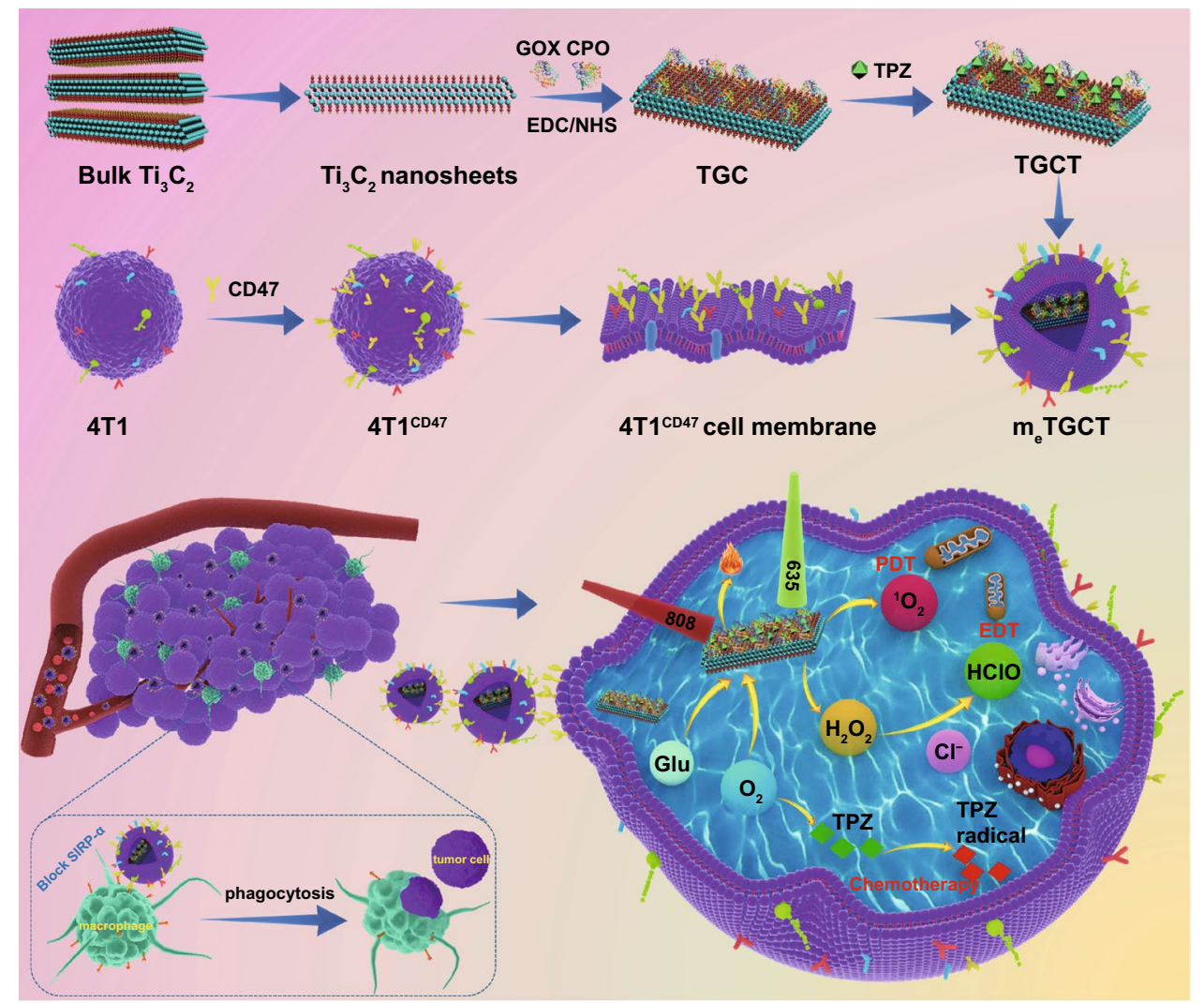

Scheme 1 Schematic diagram of the construction of bionic cascaded-enzyme nanoreactor and proposed mechanism in vivo

dynamic therapy, phototherapy and hypoxic-activated chemotherapy for efficient antitumor effects (Scheme 1). In brief, the nano-cascaded enzymes $\mathrm{Ti}_{3} \mathrm{C}_{2}$-GOX-CPO/TPZ (TGCT) were prepared by conjugating $\mathrm{GOX}$ and $\mathrm{CPO}$ onto the $\mathrm{Ti}_{3} \mathrm{C}_{2}$ 2D nanosheets with TPZ drug loading, then CD47-overexpressed cancer cell membrane biomimetic modification was utilized to form a bionic cascaded-enzyme nanoreactor (denoted as $\mathrm{m}_{\mathrm{e}} \mathrm{TGCT}$ ). As CD47 can combine with the signal regulatory protein $\alpha$ (SIRP $\alpha$ ) to form an effective "don't eat me" signal, the $\mathrm{m}_{\mathrm{e}}$ TGCT can avoid being eliminated by the innate immune system and block the phagocytosis by the first responder cells (such as macrophages) to realize long blood circulation in vivo [33, 34]. At the same time, because of superior immune escape and homologous targeting capacities, $\mathrm{m}_{\mathrm{e}}$ TGCT would preferentially accumulate in the tumor sites and target tumor cells, which could reduce side effects. Moreover, when $\mathrm{m}_{\mathrm{e}}$ TGCT arrived at the tumor site, highexpressed CD47 could also block the SIRPa receptor of the macrophage, thus enhancing the phagocytosis of tumor cells. On the other hand, once $\mathrm{m}_{\mathrm{e}}$ TGCT is internalized by tumor cells, the cascaded-enzyme consumes the glucose and $\mathrm{O}_{2}$ in tumor regions to generate the cytotoxic $\mathrm{HClO}$. Simultaneously, $\mathrm{Ti}_{3} \mathrm{C}_{2}$ can produce heat and ROS under NIR laser irradiation, and heat can accelerate the enzyme-catalyzed reaction rate and ROS production, further aggravating the hypoxic status in TME. Then, TPZ as a hypoxia-activated prodrug can be activated by reductase and further cause double-stranded DNA rupture and cell apoptosis to enhance the effects of EDT and phototherapy. Consequently, this camouflaged cascadedenzyme nanoreactor can realize amplified synergistic effects of the phototherapy/enzyme dynamic therapy and hypoxiaactivated chemotherapy to inhibit tumor growth efficiently.

\section{Experimental Methods}

\subsection{Materials and Instruments}

\subsubsection{Materials}

The transfection $\mathrm{CD} 47$-expression vector was obtained from Vector Builder Inc. (Guangzhou). $\mathrm{Ti}_{3} \mathrm{C}_{2}$ crystals were bought 
from Hangzhou Nano Technology Co. Ltd. Carbodiimide hydrochloride (EDC.HCl), N-Hydroxysuccinimide (NHS) and lipopolysaccharide (LPS) were from Sigma-Aldrich. Thiazolyl Blue Tetrazolium Bromide (MTT), Cyanine5.5 amine (Cy5.5$\mathrm{NH}_{2}$ ) and diphenylisobenzofuran (DPBF) were from Aladdin Reagents. Calcein-AM/PI and Annexin V-FITC/PI Detection Kit were bought from Key GEN Bio TECH (Shanghai, China). Phenylmethanesulfonyl fluoride (PMSF), SDS polyacrylamide gel, chemiluminescent kit, bovine serum albumin (BSA), BCA Protein Assay Kit were bought from the Beytotime Institute of Biotechnology (Guangzhou). Polyvinylidene fluoride (PVDF) membrane was from Millipore Ltd (Shanghai). The anti-CD47, anti-GAPDH and the second antibody were bought from Solarbio life Science (Guangzhou). 2', 7'-dichlorofluorescein diacetate (DCFH-DA) and 4', 6-diamidino-2-phenylindole (DAPI) were obtained from Biosharp. Fetal bovine serum and DMEM medium were acquired from Gibco Life Technologies. Anti-CD47/PE antibody was purchased from Bio Legend, Inc. (San Diego, USA). Glucose oxidase (GOX, $1 \mathrm{~g}$ ), Chloroperoxidase (CPO, 12.5 KU $\mathrm{mL}^{-1}$ ) and Coomassie blue were purchased from Sigma-Aldrich. The Amplite ${ }^{\circledR}$ Colorimetric Hypochlorite (Hypochlorous Acid) Assay Kit was from AAT Bioquest (USA). Hypoxyprobe ${ }^{\text {TM}}-1$ plus kit was from Beijing Biolead Biology SCI \& TECH Co. Ltd (Beijing), methylene blue (MB), coumarin-6 (C6) and Tirapazamine (TPZ) were from Aladdin Reagents. Mouse mammary tumor cells (4T1) and macrophages (RAW264.7) were from the cell bank of Chinese Academy of Sciences (Shanghai).

\subsubsection{Instruments}

The particle size and zeta potential were measured by Nano zetasizer (Malven). The morphologies were observed using transmission electron microscope (TEM, H7650, Japan) and field emission scanning electron microscope (CFSEM, ZEISS GeminiSEM500, Germany). The crystal structure was measured by X-ray diffraction (XRD, Bruker Quantax Flat Quad 5060, Germany). The Avanti mini extruder was obtained from Avanti Polar Lipids. The UV spectra were obtained by a spectrophotometer (DU-730, USA). Real-time detection of $\mathrm{O}_{2}$ concentration was measured by a dissolved $\mathrm{O}_{2}$ meter (JPBJ-608, Rex). The cell fluorescence images were performed using a Confocal laser scanning microscope (CLSM, FV3000, Olympus). The cell fluorescence quantitative assay was carried out using flow cytometry (FACSCalibur, BD). The cell viability was assessed with a microplate reader (Bio-Rad, model 550, USA). The temperature change was measured by an infrared thermal imager (Ti27, Fluke). The fluorescence imaging experiments in vivo were performed via IVIS Lumina Vivo Imaging System (PerkinElmer). The tissue sections were detected by Motic AE31 optical microscope (Xiamen).

\subsection{Synthesis of $\mathrm{m}_{\mathrm{e}}$ TGCT (CD47-Engineering Membrane@ $\mathrm{Ti}_{3} \mathrm{C}_{2}$-GOX-CPO/TPZ)}

\subsubsection{Extraction and Characterization of 4T1 Cell Membrane}

4T1 cells with high expression of CD47 were prepared according to our previous study by transfection using lentiviruses plasmid [35]. Subsequently, 4T1 cells were plated in a 12-well plate with incubation for $12 \mathrm{~h}$ and then were cultured with lentiviruses (multiplicity of infection (MOI) was 10) and polybrene $\left(10 \mu \mathrm{g} \mathrm{mL}^{-1}\right)$ for $24 \mathrm{~h}$. Then, the transfected $4 \mathrm{~T} 1$ $\left(4 \mathrm{~T} 1^{\mathrm{CD} 47}\right)$ cells were screened out with dihydropenicillin and were detected by CLSM and flow cytometry. Besides, the proteins of $4 \mathrm{~T} 1$ and $4 \mathrm{~T} 1{ }^{\mathrm{CD} 47}$ cells were obtained from RIPA buffer and loaded with $10 \%$ SDS polyacrylamide gel, which were then transferred to PVDF membrane and sealed with BSA for $2 \mathrm{~h}$. Finally, the membranes were treated with anti-CD47 and anti-GAPDH and then were imaged by a chemiluminescence analyzer. To obtain 4T1 cell membrane with high CD47 expression, $4 \mathrm{~T}^{\mathrm{CD} 47}$ cells were resuspended with precooled $0.25 \times$ PBS (phosphate buffer saline) containing PMSF, then the above cell solution was repeated freezing and thawing for three times and centrifuged at a speed of $3000 \mathrm{rpm} \mathrm{min}^{-1}$ $(10 \mathrm{~min})$ at $4{ }^{\circ} \mathrm{C}$, the supernatant was further centrifuged $\left(13,500 \mathrm{rpm} \mathrm{min}^{-1}, 30 \mathrm{~min}\right)$ at $4{ }^{\circ} \mathrm{C}$. Finally, $4 \mathrm{~T} 1^{\mathrm{CD} 47}$ cell membrane fragments were extruded 12 times by an Avanti mini extruder.

\subsubsection{Synthesis of $\mathrm{Ti}_{3} \mathrm{C}_{2}$ Nanosheets}

The $\mathrm{Ti}_{3} \mathrm{C}_{2}$ nanosheets were obtained by a sonication exfoliation. In brief, bulk $\mathrm{Ti}_{3} \mathrm{C}_{2}$ were added into deionized water at the concentration of $2 \mathrm{mg} \mathrm{mL}^{-1}$, and then, the dispersion was treated with an ultrasonic probe $(1200 \mathrm{~W})$ for $15 \mathrm{~h}$, followed by ultrasonic cleaning $(300 \mathrm{~W})$ for $12 \mathrm{~h}$. Then, the final dispersion was centrifuged at $7000 \mathrm{rpm} \mathrm{min}^{-1}$ for 10 min to remove large $\mathrm{Ti}_{3} \mathrm{C}_{2}$, and the suspension was further centrifuged $\left(13,000 \mathrm{rpm} \mathrm{min}^{-1}\right)$ for $30 \mathrm{~min}$ to obtain $\mathrm{Ti}_{3} \mathrm{C}_{2}$ nanosheets. 


\subsubsection{Synthesis of TGCT $\left(\mathrm{Ti}_{3} \mathrm{C}_{2}-\mathrm{GOX}-\mathrm{CPO} / \mathrm{TPZ}\right)$}

To obtain TGC, GOX (2 mg), CPO (50 U) and $\mathrm{Ti}_{3} \mathrm{C}_{2}$ nanosheets $(2 \mathrm{mg})$ were dispersed into PBS $(2 \mathrm{~mL})$ with magnetic stirring for $24 \mathrm{~h}$. During the time, EDC $\left(20 \mathrm{mg}\right.$ ) and NHS (30 mg) were joined to active $\mathrm{Ti}_{3} \mathrm{C}_{2}$ nanosheets. At last, the obtained mixture was centrifuged $\left(13,000 \mathrm{rpm} \mathrm{min}{ }^{-1}, 10 \mathrm{~min}\right)$ and rinsed with PBS to obtain TGC. TG and TC were obtained by the same above method. To obtain TGCT, TPZ $(0.5,1,2,4$ or $8 \mathrm{mg})$ was dissolved into $2 \mathrm{~mL}$ of deionized water containing $2 \mathrm{mg}$ of TGC $\left(\mathrm{Ti}_{3} \mathrm{C}_{2}\right.$-GOX-CPO) under vigorous stirring. Then, TGCT was obtained by centrifugation at the speed of $13,000 \mathrm{rpm} \mathrm{min}{ }^{-1}$, the drug loading efficiency and entrapment efficiency were calculated by UV-Vis at $470 \mathrm{~nm}$.

To obtain $\mathrm{m}_{\mathrm{e}}$ TGCT, the TGCT was mixed with equal amounts of the above obtained cell membrane, and the mixture was extruded for 12 passes by Avanti mini extruder (200 nm membrane). Finally, obtained $\mathrm{m}_{\mathrm{e}}$ TGCT was characterized by SDS-PAGE protein analysis. Specifically, $\mathrm{m}_{\mathrm{e}}$ TGCT was dissolved in RIPA lysis buffer with an ice bath for $30 \mathrm{~min}$ and prepared in SDS loading buffer. Then, we heated the samples loading buffer to $99{ }^{\circ} \mathrm{C}$. Next, the samples were loaded each well of $10 \%$ SDS polyacrylamide gel, and then, the samples were run at the voltage of $80 \mathrm{~V}$ $(0.5 \mathrm{~h})$ and $120 \mathrm{~V}(1.5 \mathrm{~h})$, the resulting polyacrylamide gel was stained by Coomassie blue and washed overnight.

The release of TPZ from $\mathrm{m}_{\mathrm{e}}$ TGCT solution $\left(1 \mathrm{mg} \mathrm{mL}^{-1}\right)$ was detected in dialysis bag $(\mathrm{MWCO}=3000 \mathrm{Da})$ and placed into $20 \mathrm{~mL}$ of PBS with shaking at $37{ }^{\circ} \mathrm{C}$. Then, $0.5 \mathrm{~mL}$ of sample solution was got from dialysis bag and the same volume of PBS was added, the release content of TPZ was detected by UV-Vis at $470 \mathrm{~nm}$. Besides, the TPZ release was detected under $808 \mathrm{~nm}$ laser irradiation with or without the addition of glucose $\left(4 \mathrm{mg} \mathrm{mL}^{-1}\right)$ and $\mathrm{Cl}^{-}(25 \mathrm{mM})$ when the sample was exposed to $808 \mathrm{~nm}$ laser $\left(1.5 \mathrm{~W} \mathrm{~cm}^{-2}, 3 \mathrm{~min}\right)$ at 2,8 , and $24 \mathrm{~h}$, respectively.

\subsection{Loading Amount and Cascade Catalytic Activity of GOX and CPO}

The loading amount of GOX and CPO was detected by BCA protein assay Kit. In brief, GOX (2 mg), CPO (50 $\mathrm{U})$ and $\mathrm{Ti}_{3} \mathrm{C}_{2}$ nanosheets $(2 \mathrm{mg}$ ) were dispersed into $2 \mathrm{~mL}$ of PBS, and then EDC (20 mg) and NHS (30 mg) were added and stirred overnight. TGC was acquired by centrifugal separation, and the supernatant was analyzed to calculate the amount of residual enzyme. The calculation of GOX and CPO loading efficiency (LE) is confirmed as follows:

$L E(\%)=\frac{\left(m_{i}-m_{r}\right) \times 100}{m_{i}}$

where $m_{i}$ and $m_{r}$ stand for the initial enzyme mass and the residual enzyme mass, respectively.

To evaluate the cascade catalytic activity of GOX and CPO, glucose $\left(4 \mathrm{mg} \mathrm{mL}^{-1}\right)$ was added into the $\mathrm{m}_{\mathrm{e}}$ TGCT $\left(50 \mu \mathrm{g} \mathrm{mL}^{-1}\right)$ solution, and then, the changes of dissolved $\mathrm{O}_{2}$ level and the $\mathrm{pH}$ were detected.

$\mathrm{HClO}$ detection was performed by $\mathrm{HClO}$ detection Kit (Amplite fluorescence method). Briefly, different samples were dispersed in PBS solution with glucose (4 mg mL $\left.{ }^{-1}\right)$ and $\mathrm{Cl}^{-}(25 \mathrm{mM})$, and laser irradiation groups were treated with $808 \mathrm{~nm}\left(1.5 \mathrm{~W} \mathrm{~cm}^{-2}, 3 \mathrm{~min}\right)$ and $635 \mathrm{~nm}\left(0.5 \mathrm{~W} \mathrm{~cm}^{-2}, 5 \mathrm{~min}\right)$ lasers, and then, the supernatants were collected and treated with $\mathrm{HClO}$ detection Kit, the $\mathrm{HClO}$ content was monitored according to the OD value of $550 \mathrm{~nm}$. Besides, $\mathrm{m}_{\mathrm{e}}$ TGCT of different concentrations were dispersed in PBS solution containing glucose $\left(4 \mathrm{mg} \mathrm{mL}^{-1}\right)$ and $\mathrm{Cl}^{-}(25 \mathrm{mM})$ and were treated with $\mathrm{HClO}$ detection $\mathrm{Kit}$, the $\mathrm{HClO}$ content was monitored according to the OD value of $550 \mathrm{~nm}$.

\subsection{Detection of Singlet Oxygen In vitro}

The production efficiency of ${ }^{1} \mathrm{O}_{2}$ in $\mathrm{m}_{\mathrm{e}}$ TGCT was detected by the absorbance change of the DPBF. Typically, $\mathrm{Ti}_{3} \mathrm{C}_{2}$, $\mathrm{m}_{\mathrm{e}} \mathrm{T}\left(\mathrm{CD} 47\right.$-engineering membrane $\left.@ \mathrm{Ti}_{3} \mathrm{C}_{2}\right)$ and $\mathrm{m}_{\mathrm{e}} \mathrm{TGCT}$ were added into DPBF ethanol solution containing $4 \mathrm{mg} \mathrm{mL}^{-1}$ of glucose and $20 \mathrm{mM}$ of $\mathrm{NaCl}$, respectively. Then, the mixture was placed in darkness and exposed to $635 \mathrm{~nm}\left(0.5 \mathrm{~W} \mathrm{~cm}^{-2}\right)$ laser. The DPBF absorption at $420 \mathrm{~nm}$ was detected at different points of time. Besides, ${ }^{1} \mathrm{O}_{2}$ quantum yields $(\Phi \Delta)$ were also detected via DPBF indicator, and the $\mathrm{O}_{2}$-saturated solution of $\mathrm{Ti}_{3} \mathrm{C}_{2}, \mathrm{~m}_{\mathrm{e}} \mathrm{T}$, $\mathrm{m}_{\mathrm{e}}$ TGCT and MB with DPBF $\left(20 \mu \mathrm{g} \mathrm{mL}^{-1}\right)$ was exposed to $635 \mathrm{~nm}$ laser $\left(0.5 \mathrm{~W} \mathrm{~cm}^{-2}\right)$ for $3 \mathrm{~min}$; the absorbance change of DPBF at $420 \mathrm{~nm}$ was recorded every $30 \mathrm{~s}$ by 
the UV-Vis system. Finally, the $\Phi \Delta$ values of all samples were calculated by the standard of $\mathrm{MB}(\Phi \Delta=0.52)$ [36].

\subsection{Detection of the Photothermal Effect In vitro}

$808 \mathrm{~nm}$ laser was used as the NIR light source to evaluate the photothermal effects of $\mathrm{m}_{\mathrm{e}}$ TGCT. Various concentrations of $\mathrm{m}_{\mathrm{e}}$ TGCT $(1.5 \mathrm{~mL})$ were added into transparent quartz plates under $808 \mathrm{~nm}$ laser $\left(1.5 \mathrm{~W} \mathrm{~cm}^{-2}\right)$ exposure, and the temperature was recorded every $30 \mathrm{~s}$. The photothermal conversion efficiency $(\eta)$ was measured by detecting the temperature change of $\mathrm{m}_{\mathrm{e}}$ TGCT solution under $808 \mathrm{~nm}$ laser $\left(1.5 \mathrm{~W} \mathrm{~cm}^{-2}\right)$.

Besides, the photothermal stability of $\mathrm{m}_{\mathrm{e}}$ TGCT was examined by the $808 \mathrm{~nm}$ laser, $\mathrm{m}_{\mathrm{e}}$ TGCT solution was exposed (5 min) and then cooled to inceptive temperature naturally with repetition (4 times). In order to investigate the impact of the physiological environment on the stability of $\mathrm{m}_{\mathrm{e}} \mathrm{TGCT}$, which was dispersed in PBS and kept at $37{ }^{\circ} \mathrm{C}$, the particle size and PDI were recorded at the various time by dynamic light scattering (DLS).

\subsection{Detection of Cellular Uptake}

The cell internalization and subcellular distribution of $\mathrm{m}_{\mathrm{e}}$ TGC were assessed with C6 fluorescent dye via flow cytometry and CLSM, respectively. At a word, 4T1 cells were cultured for $12 \mathrm{~h}$ and subsequently cultured with $\mathrm{TGC} /$ $\mathrm{C} 6\left(50 \mu \mathrm{g} \mathrm{mL}^{-1}\right)$ and $\mathrm{m}_{\mathrm{e}} \mathrm{TGC} / \mathrm{C} 6\left(50 \mu \mathrm{g} \mathrm{mL}^{-1}\right)$, and then, 4T1 cells were collected for flow cytometry detection and stained by DAPI $\left(10 \mu \mathrm{g} \mathrm{mL}^{-1}\right)$ for CLSM.

\section{7 $\mathrm{m}_{\mathrm{e}}$ TGC Promoted M1 Macrophages Phagocytosis of Tumor Cells}

To detect the impact of $\mathrm{m}_{\mathrm{e}}$ TGC on the M1 macrophage phagocytosis of $4 \mathrm{~T} 1$ cells, $1000 \mathrm{ng} \mathrm{mL}^{-1}$ of LPS was used to polarize RAW264.7 cells into M1 macrophages, which were cultured with $\mathrm{m}_{\mathrm{w}} \mathrm{TGC}$ (wild-type cell membrane@ $\mathrm{Ti}_{3} \mathrm{C}_{2}$-GOX-CPO/TPZ) and $\mathrm{m}_{\mathrm{e}} \mathrm{TGC}$ for $2 \mathrm{~h}$, respectively. After that, mCherry-labeled 4T1 cells were collected and added into per well at the quantity ratio of 1:5 (macrophages/ cancer cells). After $4 \mathrm{~h}$ incubation, M1 macrophages were analyzed via CLSM and flow cytometry.

\subsection{Cellular ROS and Thermal Imaging Evaluation}

The ROS generation of $\mathrm{m}_{\mathrm{e}}$ TGCT was confirmed using DCFH-DA. In short, $4 \mathrm{~T} 1$ cells were plated for $24 \mathrm{~h}$ and subsequently cultured with $\mathrm{m}_{\mathrm{e}}$ TGCT for $4 \mathrm{~h}$, and then DCFHDA was added into the different samples containing $\mathrm{Ti}_{3} \mathrm{C}_{2}$, $\mathrm{m}_{\mathrm{e}} \mathrm{T}\left(\mathrm{m}_{\mathrm{e}} @ \mathrm{Ti}_{3} \mathrm{C}_{2}\right), \mathrm{m}_{\mathrm{e}} \mathrm{TG}, \mathrm{m}_{\mathrm{e}} \mathrm{TC}, \mathrm{m}_{\mathrm{e}} \mathrm{TGC}$ and $\mathrm{m}_{\mathrm{e}} \mathrm{TGCT}$ $\left(50 \mu \mathrm{g} \mathrm{mL}^{-1}\right)$ for ROS detection. With or without $635 \mathrm{~nm}$ laser $\left(0.5 \mathrm{~W} \mathrm{~cm}^{-2}, 5 \mathrm{~min}\right)$ treatment, $4 \mathrm{~T} 1$ cells were analyzed via flow cytometry and CLSM.

\subsection{Intracellular Hypoxia Detection In vitro}

The intracellular hypoxia status was evaluated by Hypoxyprobe $\mathrm{TM}_{-} 1$ plus kit. The composition of hypoxyprobe-1 is a pimonidazole hydrochloride, which could be reduced by the intracellular nitroreductase to produce the stable adducts with thiol (sulphydryl) groups in the tissue, and then FITCmarked antibody (FITC-Mab1) could bind to these adducts to reflect the cellular $\mathrm{O}_{2}$ level by immunofluorescence method. In brief, $4 \mathrm{~T} 1$ cells were plated for $12 \mathrm{~h}$ of incubation, and then, the medium was replaced with $\mathrm{m}_{\mathrm{e}} \mathrm{T}, \mathrm{m}_{\mathrm{e}} \mathrm{TG}$, $\mathrm{m}_{\mathrm{e}} \mathrm{TC}$ and $\mathrm{m}_{\mathrm{e}} \mathrm{TGC}\left(50 \mu \mathrm{g} \mathrm{mL} \mathrm{m}^{-1}\right)$. After $4 \mathrm{~h}$ incubation, laser groups were treated with $635 \mathrm{~nm}$ laser $\left(0.5 \mathrm{~W} \mathrm{~cm}^{-2}, 5 \mathrm{~min}\right)$, and then, pimonidazole $\mathrm{HCl}$ was used to pre-treat the cells for $1 \mathrm{~h}$ and stained using FITC-Mab1 for another $30 \mathrm{~min}$. Finally, the cell hypoxia status was analyzed via CLSM and flow cytometry.

\subsection{Cytotoxicity Evaluation in vitro}

The cytotoxicity was measured via MTT method. 4T1 cells were cultured for $12 \mathrm{~h}$, and then, $\mathrm{m}_{\mathrm{e}} \mathrm{T}, \mathrm{m}_{\mathrm{e}} \mathrm{TG}, \mathrm{m}_{\mathrm{e}} \mathrm{TC}$, $\mathrm{m}_{\mathrm{e}} \mathrm{TGC}$, TGCT, and $\mathrm{m}_{\mathrm{e}}$ TGCT with concentration of $50 \mu \mathrm{g} \mathrm{mL}^{-1}$ were used to treat with $4 \mathrm{~T} 1$ cells for $4 \mathrm{~h}$, which were irradiated with $808 \mathrm{~nm}\left(1.5 \mathrm{~W} \mathrm{~cm}^{-2}, 3 \mathrm{~min}\right)$ and $635 \mathrm{~nm}\left(0.5 \mathrm{~W} \mathrm{~cm}^{-2}, 5 \mathrm{~min}\right)$ lasers and continued to be cultured to $24 \mathrm{~h}$. MTT ( $5 \mathrm{mg} \mathrm{mL}^{-1}$ ) was added for a further $4 \mathrm{~h}$ incubation, the absorption value was recorded at $570 \mathrm{~nm}$ after the addition of DMSO.

Besides, the efficacy of every formulation was evaluated by a live/dead cell experiment. Briefly, 4T1 cells were processed with different formulations $\left(50 \mu \mathrm{g} \mathrm{mL}^{-1}\right.$ of $\mathrm{m}_{\mathrm{e}} \mathrm{T}, \mathrm{m}_{\mathrm{e}} \mathrm{TG}, \mathrm{m}_{\mathrm{e}} \mathrm{TC}, \mathrm{m}_{\mathrm{e}} \mathrm{TGC}$, and $\mathrm{m}_{\mathrm{e}} \mathrm{TGCT}$ ) for $24 \mathrm{~h}$, and the laser irradiation conditions were the same as the MTT 
assay. Finally, the cells were stained by Calcein-AM/PI and recorded by CLSM.

Finally, the anti-proliferation capacities of $\mathrm{m}_{\mathrm{e}}$ TGCT were further measured by cell apoptosis experiments. Firstly, 4T1 cells were cultured with $\mathrm{m}_{\mathrm{e}} \mathrm{T}, \mathrm{m}_{\mathrm{e}} \mathrm{TG}, \mathrm{m}_{\mathrm{e}} \mathrm{TC}, \mathrm{m}_{\mathrm{e}} \mathrm{TGC}$, and $\mathrm{m}_{\mathrm{e}}$ TGCT at the same concentration $\left(50 \mu \mathrm{g} \mathrm{m}^{-1}\right)$ for $24 \mathrm{~h}$, and laser irradiation condition was the same as the MTT assay, and then, the cells were treated with Annexin V-FITC/ PI and detected by flow cytometry subsequently.

\subsection{Tumor Targeting Capacity of $m_{e}$ TGC}

All animal experiments were approved in agreement with the Animal Ethics Committee and Use of Sun Yat-sen University $(2,021,000,656)$. BALB/c female mice (3-5 weeks old) were given $4 \mathrm{~T} 1$ cells $\left(1 \times 10^{6}\right)$ by subcutaneous injection to create the animal model, and then, the mice were intravenously injected with $\mathrm{Ti}_{3} \mathrm{C}_{2} / \mathrm{Cy} 5.5, \mathrm{~m}_{\mathrm{w}} \mathrm{TGC} / \mathrm{Cy} 5.5$ or $\mathrm{m}_{\mathrm{e}} \mathrm{TGC} / \mathrm{Cy} 5.5\left(2 \mathrm{mg} \mathrm{kg}^{-1}\right)$ when the tumor volume reached to $100 \mathrm{~mm}^{3}$. The fluorescence images were monitored (excitation: $670 \mathrm{~nm}$, emission: $710 \mathrm{~nm}$ ) at different time. Lastly, the tumors and major organs were dissected and monitored after 24 and $120 \mathrm{~h}$ administration.

\subsection{Antitumor Evaluation in vivo}

$\mathrm{BALB} / \mathrm{c}$ female mice were given $4 \mathrm{~T} 1$ cells by subcutaneous injection to create the animal model. After fed for 7 days, the mice ( $n=5$ per group) were intravenously injected with different samples at a dosage $2 \mathrm{mg} \mathrm{kg}^{-1}$ as follows: PBS, $\mathrm{m}_{\mathrm{e}} \mathrm{T}$ (CD47-engineering membrane $@ \mathrm{Ti}_{3} \mathrm{C}_{2}$ ), $\mathrm{m}_{\mathrm{e}} \mathrm{TG}$ (CD47-engineering membrane $@ \mathrm{Ti}_{3} \mathrm{C}_{2}$-GOx), TGC $\left(\mathrm{Ti}_{3} \mathrm{C}_{2}\right.$-GOX-CPO), $\mathrm{m}_{\mathrm{e}} \mathrm{TGC}$ (CD47-engineering membrane @ $\mathrm{Ti}_{3} \mathrm{C}_{2}$-GOX-CPO), TGCT $\left(\mathrm{Ti}_{3} \mathrm{C}_{2}-\mathrm{GOX}-\mathrm{CPO} /\right.$ TPZ), $\mathrm{m}_{\mathrm{e}} \mathrm{TGCT}$ (CD47-engineering membrane@ $\mathrm{Ti}_{3} \mathrm{C}_{2}$ GOX-CPO/TPZ), TGCT+laser, $\mathrm{m}_{\mathrm{e}} \mathrm{TCGT}+$ laser, at the first day and fourth day, respectively. Then, tumors of the laser groups were irradiated by $808 \mathrm{~nm}\left(1.5 \mathrm{~W} \mathrm{~cm}^{-2}, 2 \mathrm{~min}\right)$ and $635 \mathrm{~nm}\left(0.5 \mathrm{~W} \mathrm{~cm}^{-2}, 5 \mathrm{~min}\right)$ lasers at $12 \mathrm{~h}$ post-injection. And the tumor volume and body weight were measured regularly during a month. Afterward, the major organs were peeled for hematoxylin and eosin $(\mathrm{H} \& \mathrm{E})$ and terminal transferase dUTP (TUNEL) detection, and the tumor tissues were weighed and photographed. The tumor volume was calculated via the formula: $\mathrm{V}=$ length $\times(\text { width })^{2} / 2$, and $\mathrm{V} /$ $\mathrm{V}_{0}$ in each group was used to normalize tumor volume, $\mathrm{V}_{0}$ is the inceptive tumor volume. Furthermore, obtained serum was used for evaluating the alanine aminotransferase (ALT), aspartate aminotransferase (AST), albumin (ALB), alkaline phosphatase (ALP), blood urea nitrogen (BUN), creatinine (CR), $\gamma$-glutamyltransferase $(\gamma$-GT), total protein (TP) and glucose (GLU) values. In addition, the tumors were stained FITC-Mab1 by immunofluorescence staining to assess the deoxy-generation ability of $\mathrm{m}_{\mathrm{e}}$ TGCT in vivo.

\subsection{Statistical Analysis}

All data were used in the manuscript as mean \pm standard deviation. Statistical analysis was constructed by the twotailed Student's t test.

\section{Results and Discussion}

\subsection{Characterization of 4T1 Cell Membrane with High-expressed CD47}

To obtain 4T1 cell membrane with high-expressed CD47, we firstly transfected $4 \mathrm{~T} 1$ cells with lentiviruses vectors to prepare gene-engineering $4 \mathrm{~T} 1$ cells with overexpression of $\mathrm{CD} 47$, and the transfected $4 \mathrm{~T} 1$ cells $\left(4 \mathrm{~T} 1^{\mathrm{CD} 47}\right)$ were detected using anti-CD47/PE staining by CLSM and flow analysis. As illustrated in Fig. 1a, the non-transfected 4T1 cell group showed slightly red fluorescence signal, while $4 \mathrm{~T} 1{ }^{\mathrm{CD} 47}$ cells displayed the strongest fluorescence signal intensity, verifying the successful transfection of 4T1 cells with high CD47 expression. Quantitatively, the percentage of CD47/PE positive cells in $4 \mathrm{~T} 1{ }^{\mathrm{CD} 47}$ cells group reached $98.4 \%$, which was dramatically as high as that in $4 \mathrm{~T} 1$ cells group (Fig. 1b), and the fluorescence intensity of $4 \mathrm{~T} 1{ }^{\mathrm{CD} 47}$ cells was 12.8 times as vigorous as that of $4 \mathrm{~T} 1$ cells by quantitative analysis (Fig. 1c). Besides, it was also identified the high expression of CD47 on $4 \mathrm{~T} 1{ }^{\mathrm{CD} 47}$ cells by western blot analysis (Fig. S1). These results all suggested the successful preparation of 4T1 cells with high-CD47 expression. 


\subsection{Characterization of $\mathrm{m}_{\mathrm{e}}$ TGCT (CD47-engineering Membrane @ $\mathrm{Ti}_{3} \mathrm{C}_{2}$-GOX-CPO/TPZ)}

The cascaded-enzyme nanoreactor $\left(\mathrm{m}_{\mathrm{e}} \mathrm{TGCT}\right)$ was synthesized by conjugating GOX and CPO onto the surface of $\mathrm{Ti}_{3} \mathrm{C}_{2}$ nanosheets loading with TPZ and further encapsulated with 4T1 cell membrane with high-CD47 expression (Fig. 2a). $\mathrm{Ti}_{3} \mathrm{C}_{2}$ nanosheets were prepared from the bulk layer-structured $\mathrm{Ti}_{3} \mathrm{C}_{2}$ by ultrasonication. Scanning electron microscopy (SEM) images showed the accordion-like layer structures of origin $\mathrm{Ti}_{3} \mathrm{C}_{2}$, and the element mapping of the bulk $\mathrm{Ti}_{3} \mathrm{C}_{2}$ sample confirmed the absence of the $\mathrm{Al}$ element and the existence of $\mathrm{O}$ and $\mathrm{F}$ elements (Fig. 2b). The morphology of obtained $\mathrm{Ti}_{3} \mathrm{C}_{2}$ nanosheets was characterized by TEM (Fig. 2c) and SEM (Fig. S2a) images, revealing the ultrathin and transparent flake with the size of $100 \mathrm{~nm}$ and exhibiting the typical 2D topology. The atomic force microscopy (AFM) image suggested that the thickness of the as-synthesized $\mathrm{Ti}_{3} \mathrm{C}_{2}$ nanosheets was $\sim 6 \mathrm{~nm}$ (Fig. $2 \mathrm{~d}$ ). The exfoliated $\mathrm{Ti}_{3} \mathrm{C}_{2}$ nanosheets also performed a size of $115 \mathrm{~nm}$ (Fig. 2e) with a charge of $-28.9 \mathrm{mV}$ (Fig. 2f). The infrared spectroscopy (Fig. S2b) and Raman spectroscopy (Fig. S2c) confirmed that the surface of as-exfoliated $\mathrm{Ti}_{3} \mathrm{C}_{2}$ nanosheets was rich in $-\mathrm{COOH}$ and $-\mathrm{OH}$ groups. Subsequently, GOX and $\mathrm{CPO}$ were conjugated onto $\mathrm{Ti}_{3} \mathrm{C}_{2}$ nanosheets with amido bonds, and the loading efficiency (LE) was detected to be $15.69 \%$. For comparison, the GOX LE was $20.79 \%$ for $\mathrm{Ti}_{3} \mathrm{C}_{2}$-GOX (TG) and CPO LE was $9.35 \%$ for $\mathrm{Ti}_{3} \mathrm{C}_{2}$-CPO (TC), respectively (Fig. S3). After loading, the particle size of $\mathrm{Ti}_{3} \mathrm{C}_{2}$ nanosheets $(115 \mathrm{~nm})$ increased to $\sim 145 \mathrm{~nm}$ (Fig. 2e), and the zeta potential $(-28.9 \mathrm{mV})$ slightly changed to $-24.5 \mathrm{mV}$ (Fig. 2f), implying the successful loading of GOX and CPO. Afterward, hypoxia-activated prodrug TPZ was loaded onto $\mathrm{Ti}_{3} \mathrm{C}_{2}$-GOX-CPO (TGC) through physical interactions. The ultraviolet-visible (UV-Vis) spectra demonstrated the successful loading of TPZ in the TGC (Fig. S4a), when the ratio of TGC/TPZ was 1:2, the loading efficiency (LE) and entrapment efficiency (EE) were 63.06\%
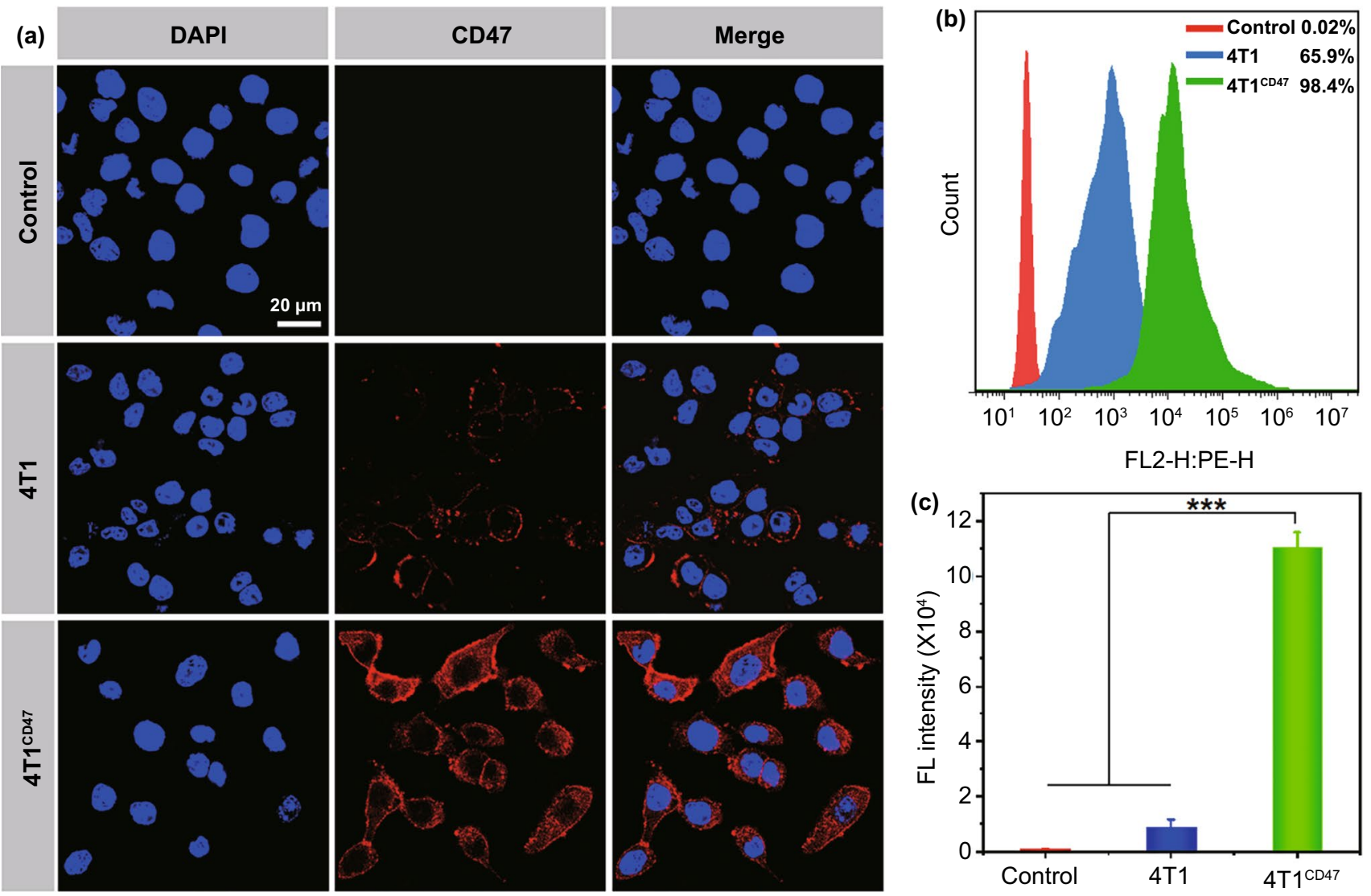

Fig. 1 a CLSM images and b flow histogram of the level of CD47 expression. c Quantitative analysis of the CD47 expression. (*** $p<0.001$, $n=3$ ) 
and $85.12 \%$ (Fig. S4b), respectively. The zeta potential of $\mathrm{Ti}_{3} \mathrm{C}_{2}$-GOX-CPO/TPZ (TGCT) increased to $-18.5 \mathrm{mV}$ (Fig. 2f). To obtain $\mathrm{m}_{\mathrm{e}}$ TGCT, TGCT was embedded with 4T1 cell membrane with CD47 high expression by repeated extrusion. As shown in Fig. S5, $\mathrm{m}_{\mathrm{e}}$ TGCT exhibited a transverse dimension $(160 \mathrm{~nm})$ and transparent membrane coating, confirming the successful packaging of 4T1 cell membrane. What's more, the size of $\mathrm{m}_{\mathrm{e}}$ TGCT widened to $180 \mathrm{~nm}$ (Fig. 2e), and the zeta charge swelled to -14.6 mV (Fig. 2f). In addition, the protein expression of $\mathrm{m}_{\mathrm{e}} \mathrm{TGCT}$ was detected by SDS-PAGE identification, and 4T1 cell membrane proteins were largely retained, and the bands of GOX (80 kDa) and CPO (46 kDa) were also observed in the $\mathrm{m}_{\mathrm{e}}$ TGCT group (Fig. S6), confirming that GOX and CPO were successfully accommodated in $\mathrm{m}_{\mathrm{e}}$ TGCT. These results all verified the successful preparation of $\mathrm{m}_{\mathrm{e}}$ TGCT. Of special note, the hydrodynamic size and PDI of $\mathrm{m}_{\mathrm{e}}$ TGCT were kept constant for at least 7 days, and the good dispersion of $\mathrm{m}_{\mathrm{e}} \mathrm{TGCT}$ in PBS was observed after 7 days in contrast to the precipitation occurring in TGCT, confirming the excellent stability of $\mathrm{m}_{\mathrm{e}}$ TGCT in the physiological condition (Fig. S7). Moreover, almost no visible difference was observed in X-ray diffraction (XRD) patterns among $\mathrm{m}_{\mathrm{e}} \mathrm{TGCT}, \mathrm{Ti}_{3} \mathrm{C}_{2}$ nanosheets and the bulk $\mathrm{Ti}_{3} \mathrm{C}_{2}$ (Fig. $2 \mathrm{~g}$ ), indicating that $\mathrm{m}_{\mathrm{e}}$ TGCT reserved the uniform crystal structure and crystallinity as $\mathrm{Ti}_{3} \mathrm{C}_{2}$.

\subsection{Detection of Cascade Catalytic Reactions and Drug Release}

It has been reported that chemical modifications could reduce the catalytic capabilities of enzymes [37]. Thus, the catalytic activities of GOX and CPO in $\mathrm{m}_{\mathrm{e}}$ TGCT were evaluated. GOX catalyzes glucose to generate $\mathrm{H}_{2} \mathrm{O}_{2}$ and
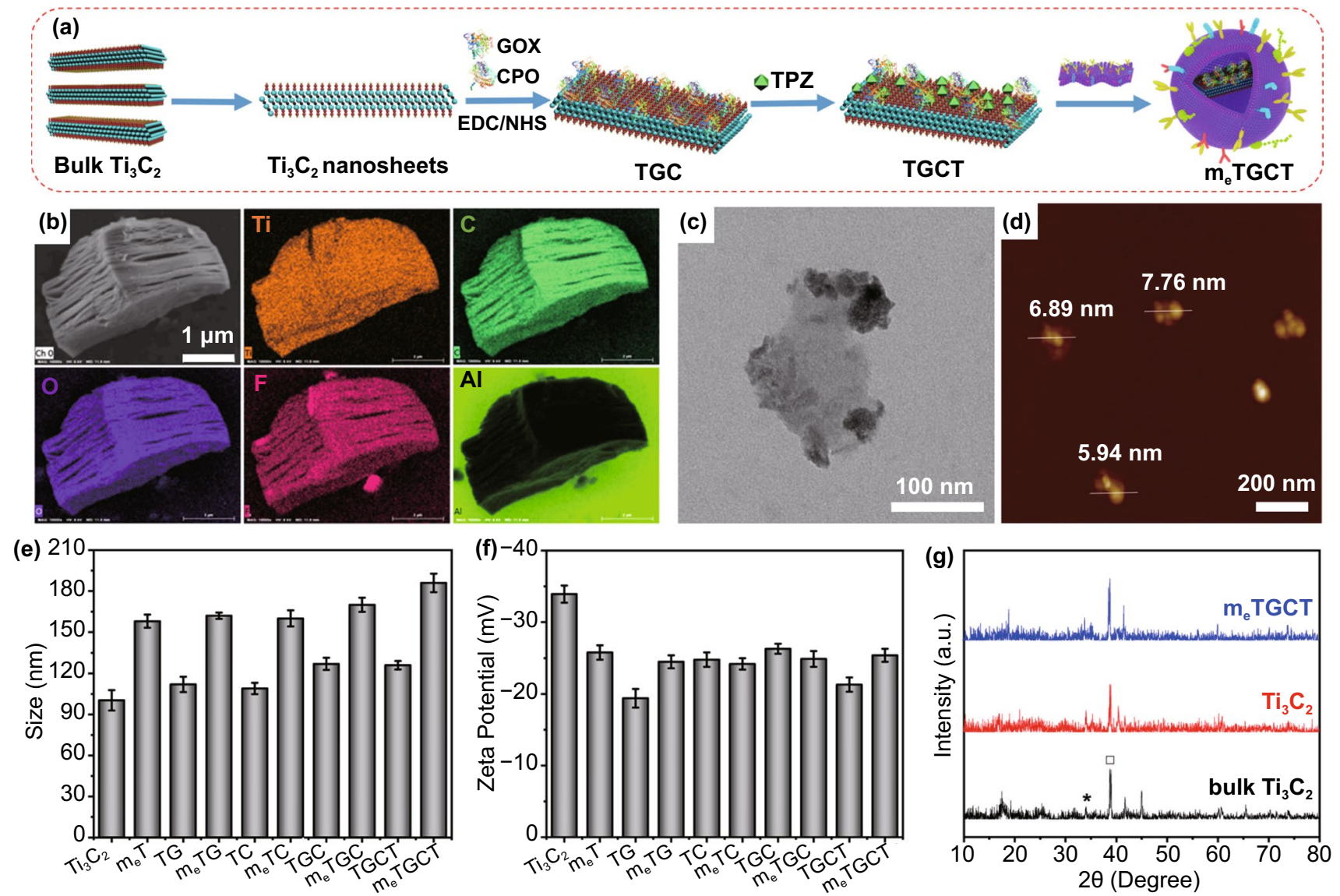

Fig. 2 a Design principle of the synthesis of $\mathrm{m}_{\mathrm{e}}$ TGCT. b SEM and element mapping of the bulk $\mathrm{Ti}_{3} \mathrm{C}_{2}$. $\mathbf{c}$ TEM image of Ti $\mathrm{C}_{2}$ nanosheets. d AFM image of the exfoliated $\mathrm{Ti}_{3} \mathrm{C}_{2}$ nanosheets. e The size and $\mathbf{f}$ apparent zeta charge of $\mathrm{Ti}_{3} \mathrm{C}_{2}, \mathrm{~m}_{\mathrm{e}} \mathrm{T}, \mathrm{TG}, \mathrm{m}_{\mathrm{e}} \mathrm{TG}, \mathrm{TC}, \mathrm{m}_{\mathrm{e}} \mathrm{TC}, \mathrm{TGC}, \mathrm{m}_{\mathrm{e}} \mathrm{TGC}$, TGCT, $\mathrm{m}_{\mathrm{e}}$ TGCT. $\mathrm{g}$ XRD images of the bulk $\mathrm{Ti}_{3} \mathrm{C}_{2}, \mathrm{Ti}_{3} \mathrm{C}_{2}$ nanosheets and $\mathrm{m}_{\mathrm{e}}$ TGCT 
gluconic acid under $\mathrm{O}_{2}$, leading to $\mathrm{pH}$ decrease and $\mathrm{O}_{2}$ consumption [38-40], and then, $\mathrm{CPO}$ could catalyze $\mathrm{H}_{2} \mathrm{O}_{2}$ and $\mathrm{Cl}^{-}$to produce $\mathrm{HClO}$. On the basis of these, the cascadedenzyme catalytic capacities of $\mathrm{m}_{\mathrm{e}}$ TGCT were measured by $\mathrm{O}_{2}$ consumption, $\mathrm{pH}$ decrease and $\mathrm{HClO}$ generation. Firstly, the dissolved $\mathrm{O}_{2}$ level of various groups in PBS containing $4 \mathrm{mg} \mathrm{mL}^{-1}$ of glucose and $25 \mathrm{mM}$ of $\mathrm{Cl}^{-}$were measured by an $\mathrm{O}_{2}$ probe. As displayed in Fig. 3a, $\mathrm{m}_{\mathrm{e}} \mathrm{TC}$ group exhibited similar results as the control group, indicating that $\mathrm{m}_{\mathrm{e}} \mathrm{TC}$ did not consume $\mathrm{O}_{2}$. However, with the addition of GOX, the dissolved $\mathrm{O}_{2}$ level quickly declined and gradually reached a platform. The $\mathrm{O}_{2}$ level of $\mathrm{m}_{\mathrm{e}} \mathrm{TG}$ gradually decreased from $8.1 \mathrm{mg} \mathrm{L}^{-1}$ to a balanceable value of $1.4 \mathrm{mg}$ $\mathrm{L}^{-1}$ within $10 \mathrm{~min}$, and the consumption rate of $\mathrm{O}_{2}$ obviously increased in $\mathrm{m}_{\mathrm{e}}$ TGC and $\mathrm{m}_{\mathrm{e}}$ TGCT groups, indicating that the presence of CPO accelerated GOX-catalyzed reaction activities. Importantly, under the $808+635 \mathrm{~nm}$ lasers irradiation, the $\mathrm{O}_{2}$ level in $\mathrm{m}_{\mathrm{e}}$ TGCT group decreased faster and reached $0.8 \mathrm{mg} \mathrm{L}^{-1}$ within $4 \mathrm{~min}$, which might be because that $635 \mathrm{~nm}$ laser irradiation could induce the energy transfer of $\mathrm{Ti}_{3} \mathrm{C}_{2}$ that reacts with $\mathrm{O}_{2}$ to produce ${ }^{1} \mathrm{O}_{2}$, and the increased temperature caused by $808 \mathrm{~nm}$ laser could enhance the enzymatic activities of GOX and CPO. Besides, the $\mathrm{O}_{2}$ consumption rate curves in Fig. $3 \mathrm{a}$ accorded well with the exponential equation $\left(\mathrm{y}=\mathrm{a} \times \mathrm{e}^{-\mathrm{kx}}+\mathrm{b}\right)$, where $x$ and $y$ were the reaction time and $\mathrm{O}_{2}$ concentration, respectively. The constant $k$ interpreted as the $\mathrm{O}_{2}$ consumption rate is shown in Fig. 3b, demonstrating $\mathrm{m}_{\mathrm{e}}$ TGCT could rapidly consume $\mathrm{O}_{2}$ with laser irradiation. Considering that the temperature enhancement by laser irradiation might accelerate enzymatic catalytic rate, the photothermal effect of $\mathrm{m}_{\mathrm{e}}$ TGCT was also evaluated via $808 \mathrm{~nm}$ laser. As shown in Fig. S8a, $\mathrm{m}_{\mathrm{e}}$ TGCT displayed a photothermal effect with concentration and time dependence, the temperature of $\mathrm{m}_{\mathrm{e}}$ TGCT $\left(25 \mu \mathrm{g} \mathrm{mL}^{-1}\right)$ rapidly added up to $18{ }^{\circ} \mathrm{C}$ under $808 \mathrm{~nm}$ laser irradiation for $10 \mathrm{~min}$, exhibiting a superior photothermal capability, while temperature of solution without $\mathrm{m}_{\mathrm{e}}$ TGCT rose mildly $\left(\Delta \mathrm{T} \approx 1.7^{\circ} \mathrm{C}\right)$. The photothermal stability is further measured and shown in Fig. S8b, and there was no distinct variation in photothermal capacity of $\mathrm{m}_{\mathrm{e}}$ TGCT during four heating cycles, presenting excellent photothermal stability. Besides, the photothermal conversion efficiency of $\mathrm{m}_{\mathrm{e}} \mathrm{TGCT}$ was computed as $53.87 \%$ based on the cooling curve (Fig. $\mathrm{S} 8 \mathrm{c}$ ), which is remarkably higher than most photothermal agents (PTAs) such as black phosphorus (BP) nanoparticles (29.47\%), graphene oxide (25\%), $\mathrm{MoS}_{2}$ nanosheets (27.6\%),
PEG modified antimonene quantum dots (PEG-AMQDs, $45.5 \%)$ [41, 42]. Therefore, the results proved that $m_{e}$ TGCT possessed good photothermal conversion properties, which would benefit for improving the enzyme activity. Next, we further evaluated the enzymatic activity of $\mathrm{m}_{\mathrm{e}}$ TGCT by $\mathrm{pH}$ change in PBS containing $4 \mathrm{mg} \mathrm{mL}^{-1}$ of glucose and $25 \mathrm{mM}$ of $\mathrm{Cl}^{-}$, which was monitored by a $\mathrm{pH}$ meter. As clarified in Fig. S9, pH values of PBS (containing $4 \mathrm{mg} \mathrm{mL}^{-1}$ of glucose) remained constant at 7.4 without GOX treatment. With the increase in concentration of additional GOX, the $\mathrm{pH}$ of glucose solution gradually declined and dropped to 4.24 when the concentration of GOX was $50 \mu \mathrm{g} \mathrm{mL}^{-1}$, verifying that GOX could improve glucose oxygenolysis in the manner of time and concentration dependence. In addition, the $\mathrm{pH}$ values of glucose solution with different treatments were detected to evaluate the catalytic activity of $\mathrm{m}_{\mathrm{e}}$ TGCT (Fig. 3c). The $\mathrm{pH}$ values of the control and $\mathrm{m}_{\mathrm{e}} \mathrm{TC}$ groups remained constant, while the $\mathrm{m}_{\mathrm{e}} \mathrm{TG}$ group exhibited certain $\mathrm{pH}$ changes, illustrating the catalytic activities of $\mathrm{m}_{\mathrm{e}} \mathrm{TG}$ were retained. Compared with $\mathrm{m}_{\mathrm{e}}$ TG group, $\mathrm{m}_{\mathrm{e}}$ TGC and $\mathrm{m}_{\mathrm{e}}$ TGCT groups exhibited an enhanced drop of $\mathrm{pH}$, demonstrating that $\mathrm{CPO}$ could accelerate the GOX-catalyzed reaction process, while the significantly reduced $\mathrm{pH}$ values were shown in the $\mathrm{m}_{\mathrm{e}} \mathrm{TGCT}+\mathrm{L}$ group, which was ascribed to the enhanced catalytic reactivity by hyperthermia induced by laser irradiation.

The cascade catalytic activity of $\mathrm{m}_{\mathrm{e}} \mathrm{TGCT}$ was further evaluated by CPO-catalyzed product. CPO could catalyze $\mathrm{H}_{2} \mathrm{O}_{2}$ and $\mathrm{Cl}^{-}$into highly cytotoxic $\mathrm{HClO}$, so we detected the generated $\mathrm{HClO}$ of the $\mathrm{m}_{\mathrm{e}} \mathrm{TG}, \mathrm{m}_{\mathrm{e}} \mathrm{TC}, \mathrm{m}_{\mathrm{e}} \mathrm{TGC}, \mathrm{m}_{\mathrm{e}}$ TGCT, and $\mathrm{m}_{\mathrm{e}} \mathrm{TGCT}+\mathrm{L}$ in PBS with the addition of glucose ( $4 \mathrm{mg} \mathrm{mL}^{-1}$ ) and $\mathrm{Cl}^{-}(25 \mathrm{mM})$ to imitate physiological environment. As revealed in Fig. $3 \mathrm{~d}, \mathrm{~m}_{\mathrm{e}} \mathrm{TGC}$ group exhibited enhanced $\mathrm{HClO}$ generation capacity compared with the $\mathrm{m}_{\mathrm{e}} \mathrm{TG}$ and $\mathrm{m}_{\mathrm{e}}$ TC groups, demonstrating the successful cascaded catalysis of GOX and CPO enzymes. The absence of either GOX or CPO could restrict the catalytic activity and limit the generation of $\mathrm{HClO}$. After laser irradiation, the $\mathrm{HClO}$ generation of the $\mathrm{m}_{\mathrm{e}}$ TGCT group further increased, which was attributed to the increase in temperature by laser irradiation. Meanwhile, the $\mathrm{HClO}$ generation content of $\mathrm{m}_{\mathrm{e}}$ TGCT performed a concentration-dependent manner (Fig. 3e). To further explore the $\mathrm{HClO}$ generation capacity of the $\mathrm{CPO}$ catalysis, we evaluated the $\mathrm{HClO}$ content in the $\mathrm{m}_{\mathrm{e}}$ TGCT group with additional $\mathrm{H}_{2} \mathrm{O}_{2}$, glucose or $\mathrm{Cl}^{-}$in PBS. As shown in Fig. S10, the generated $\mathrm{HClO}$ content 

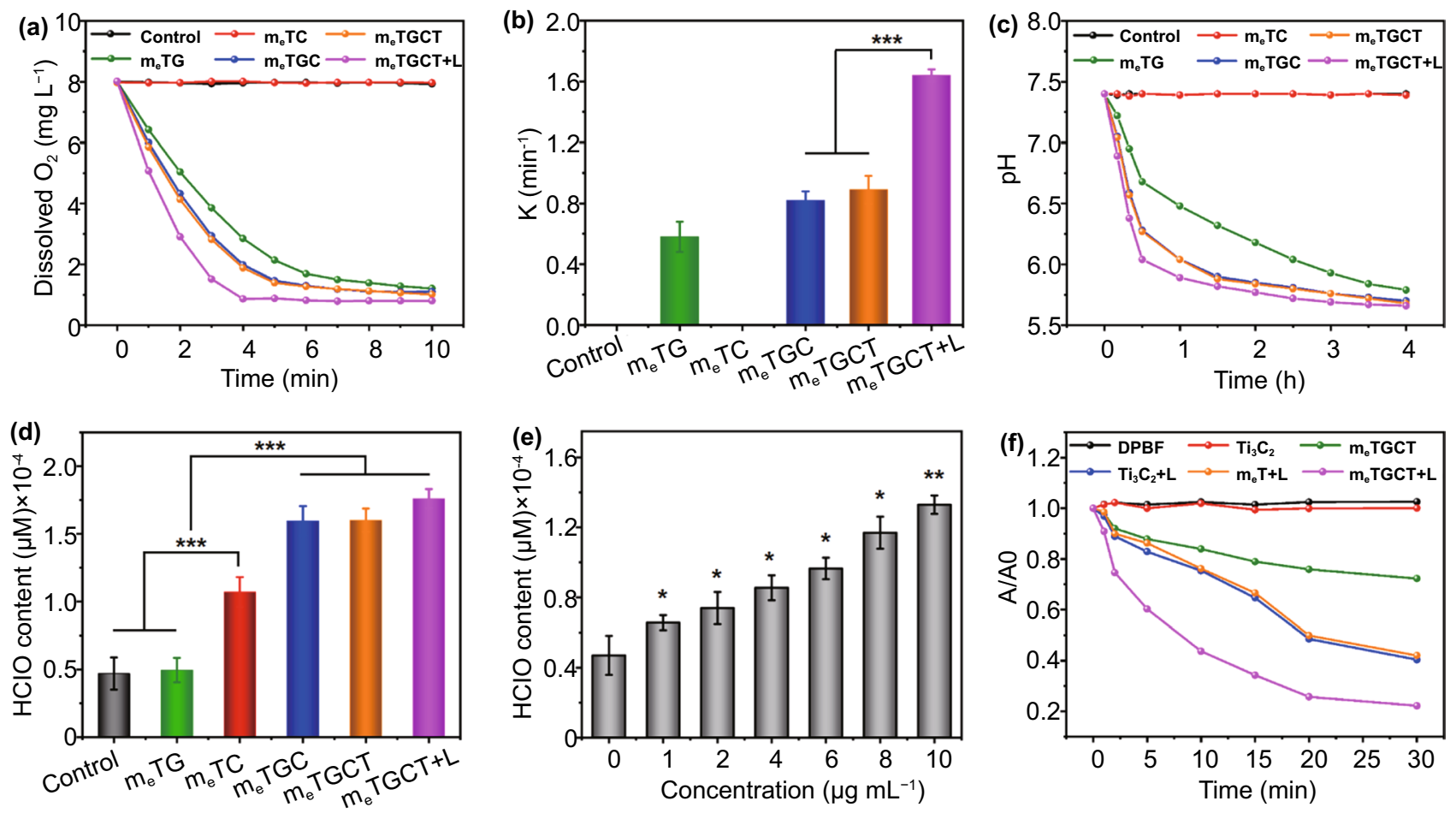

Fig. 3 a Changes of dissolved $\mathrm{O}_{2}$ in PBS containing various samples with/without $635 \mathrm{~nm}\left(0.5 \mathrm{~W} \mathrm{~cm}^{-2}\right)$ and $808 \mathrm{~nm}\left(1.5 \mathrm{~W} \mathrm{~cm}^{-2}\right)$ lasers under $4 \mathrm{mg} \mathrm{mL}^{-1}$ of glucose and $25 \mathrm{mM}$ of $\mathrm{Cl}^{-}$. b O $\mathrm{O}_{2}$ consumption rates based on a. c Changes of $\mathrm{pH}$ in PBS containing different samples. d HClO production content of PBS containing different samples. e HClO production content of PBS containing $\mathrm{m}_{\mathrm{e}}$ TGCT with different concentrations in the presence of $4 \mathrm{mg} \mathrm{mL}^{-1}$ of glucose and $25 \mathrm{mM} \mathrm{of} \mathrm{Cl}^{-}, p$ values were contrast with the group (concentration: $0 \mu \mathrm{g} \mathrm{mL}{ }^{-1}$ ). $\mathbf{f ~ A} / \mathrm{A} 0$ of the DPBF treated with $\mathrm{Ti}_{3} \mathrm{C}_{2}, \mathrm{~m}_{\mathrm{e}} \mathrm{T}$ and $\mathrm{m}_{\mathrm{e}} \mathrm{TGCT}$ with or without $635 \mathrm{~nm}$ light irradiation. $(* * * p<0.001, * * p<0.01, * p<0.05, \mathrm{n}=3)$

gradually increased with the incremental concentration of $\mathrm{H}_{2} \mathrm{O}_{2}$, glucose or $\mathrm{Cl}^{-}$, demonstrating the significant impacts of $\mathrm{H}_{2} \mathrm{O}_{2}$, glucose and $\mathrm{Cl}^{-}$for the cascaded catalysis. Afterward, the relative enzyme activities of GOX, CPO in different samples with or without laser irradiation are assessed in Fig. $\mathrm{S} 11$, and $\mathrm{m}_{\mathrm{e}} \mathrm{TGC}$ exhibited increased enzymatic activity of GOX and CPO compared to $\mathrm{m}_{\mathrm{e}} \mathrm{TG}$ and $\mathrm{m}_{\mathrm{e}} \mathrm{TC}$ due to the cascaded-enzyme reaction, and $\mathrm{m}_{\mathrm{e}}$ TGCT with laser irradiation further improved the enzyme activity of both GOX and $\mathrm{CPO}$, which could be ascribed to the rise of temperature. The above results indicated that the cascaded-enzyme nanoreactor possessed excellent enzyme catalytic capacity.

Finally, the ${ }^{1} \mathrm{O}_{2}$ generation capacity of $\mathrm{m}_{\mathrm{e}}$ TGCT was evaluated by DPBF indicator. As shown in Fig. 3f, compared with DPBF alone group, the rapid downswing of absorbance ratio at $420 \mathrm{~nm}$ was observed in $\mathrm{Ti}_{3} \mathrm{C}_{2}+\mathrm{L}$ and $\mathrm{m}_{\mathrm{e}} \mathrm{T}+\mathrm{L}$ solution within $30 \mathrm{~min}$, indicating the excellent ${ }^{1} \mathrm{O}_{2}$ generation capacity of $\mathrm{Ti}_{3} \mathrm{C}_{2}$, and cell membrane coating did not influence the ROS generation capacity of $\mathrm{Ti}_{3} \mathrm{C}_{2}$. A sharper downtrend was observed in $\mathrm{m}_{\mathrm{e}} \mathrm{TGCT}+\mathrm{L}$ solution owing to the combination of the cascade enzymatic catalysis and photodynamic effect, and the ${ }^{1} \mathrm{O}_{2}$ quantum yield of $\mathrm{m}_{\mathrm{e}} \mathrm{TGCT}$ increased from 0.18 without laser irradiation to 0.60 with laser irradiation (Fig. S12). Therefore, it could be concluded that $\mathrm{m}_{\mathrm{e}}$ TGCT possessed a significantly superior capacity of ${ }^{1} \mathrm{O}_{2}$ generation, which is promising for tumor treatment studies in vitro and in vivo.

The TPZ release is determined in Fig. S13. Compared with TPZ-releasing percentage of $26.1 \%$ under normal conditions, $808 \mathrm{~nm}$ laser irradiation enhanced the TPZ release due to the heat effect produced by $\mathrm{Ti}_{3} \mathrm{C}_{2}$. Especially, nearly of $65.9 \%$ of TPZ was released from $\mathrm{m}_{\mathrm{e}}$ TGCT under the existence of glucose and $\mathrm{Cl}^{-}$, it could be deduced that $\mathrm{m}_{\mathrm{e}}$ TGCT catalyzed the glucose to generate gluconic acid, which decreased the electrostatic interaction between TPZ and $\mathrm{Ti}_{3} \mathrm{C}_{2}$, thus accelerating the drug release $[43,44]$. 


\subsection{Cellular Uptake Study of $m_{\mathrm{e}}$ TGC}

It had been reported that cancer cell membrane-coated nanocarriers exhibited preferential homologous tumor targeting capacity [45-49]. Thus, the homologous targeting capacity of $\mathrm{m}_{\mathrm{e}} \mathrm{TGC}$ on $4 \mathrm{~T} 1$ cells was measured via flow cytometry and CLSM, and C6 dye was defined as a fluorescence probe to label $\mathrm{m}_{\mathrm{e}}$ TGC. As illustrated in Fig. S14, only tiny amounts of $\mathrm{C} 6$ in cells were observed after $10 \mathrm{~h}$ incubation with the pure $\mathrm{C} 6$, the mean fluorescence intensities of TGC/ $\mathrm{C} 6$ enhanced over time and achieved the maximum at $8 \mathrm{~h}$. By comparison, $\mathrm{m}_{\mathrm{e}} \mathrm{TGC} / \mathrm{C} 6$ group exhibited stronger fluorescence intensities at all times, indicating the well homologous targeting ability. Besides, the intracellular locations of TGC and $\mathrm{m}_{\mathrm{e}}$ TGC against $4 \mathrm{~T} 1$ cells were detected by CLSM (Fig. 4a--c), the signal (green) of the C6-labeled cascadedenzyme nanoreactor surrounding the nuclei in the $\mathrm{m}_{\mathrm{e}} \mathrm{TGC} /$ C6 group was strongest among all groups, and the quantitative flow cytometry analysis showed the fluorescence intensity of $\mathrm{m}_{\mathrm{e}}$ TGC/C6 group was 1.9 times as high as that of TGC/C6 group (Fig. 4c), further indicating cell membrane coating could improve tumor cell uptake for the cascadedenzyme nanoreactor.

\section{5 $\mathrm{m}_{\mathrm{e}}$ TGC Promoted M1 Macrophages Phagocytosis of Cancer Cells}

CD47, overexpressed on the surface of $\mathrm{m}_{\mathrm{e}}$ TGC, could interact with SIRP $\alpha$ presented on macrophages and protected $\mathrm{m}_{\mathrm{e}}$ TGC from the phagocytosis by macrophages through sending "don't eat me" signal. At the same time, CD47overexpressed $\mathrm{m}_{\mathrm{e}} \mathrm{TGC}$ would block the interaction between macrophages and tumor cells through competitively occupying SIRP $\alpha$, which could enhance the macrophage-mediated phagocytosis for tumor cells [33, 34]. Therefore, we firstly constructed cellular uptake experiments to confirm the immune escape capacity of the $\mathrm{m}_{\mathrm{e}} \mathrm{TGC}$ by flow cytometry. As shown in Fig. S15, an obviously decreased fluorescence intensity of cells treated with $\mathrm{m}_{\mathrm{e}} \mathrm{TGC/C6}$ was found as compared to the TGC/C6 group, and the cell uptake of TGC/ C6 was three times as strong as that of $\mathrm{m}_{\mathrm{e}} \mathrm{TGC} / \mathrm{C} 6$ group, indicating that coating TGC with CD47 high-expressed 4T1 cell membrane could effectively inhibit the immune recognition to achieve immune escape. To evaluate whether $\mathrm{m}_{\mathrm{e}}$ TGC could induce M1 macrophages-mediated 4T1 cells phagocytosis, we pretreated $\mathrm{M} 1$ macrophages with $\mathrm{m}_{\mathrm{e}} \mathrm{TGC}$ for $2 \mathrm{~h}$ and then explored the co-culture of M1 macrophages and mCherry-labeled $4 \mathrm{~T} 1$ cells to investigate the phagocytosis effect of macrophages by CLSM and flow cytometry. As clarified in Fig. 4d, the red signal (mCherry-labeled tumor cells) in the $\mathrm{m}_{\mathrm{e}}$ TGC group was obviously stronger than that of in control and $\mathrm{m}_{\mathrm{w}} \mathrm{TGC}$ (wild-type cell membrane-coated TGC) groups, indicating that high-expressed CD47 on the surface of the $\mathrm{m}_{\mathrm{e}} \mathrm{TGC}$ could promote macrophages-mediated 4T1 cells phagocytosis, which was because that CD47 on $\mathrm{m}_{\mathrm{e}}$ TGCT could competitively combine with SIRP $\alpha$, thus increasing the interaction between macrophages and 4T1 cells [50-53]. Similar results were confirmed in flow cytometry analysis (Fig. 4e, f), the fluorescence signal in $\mathrm{m}_{\mathrm{e}}$ TGC group was three times as strong as that in $\mathrm{m}_{\mathrm{w}}$ TGC group, further clarifying the $\mathrm{m}_{\mathrm{e}}$ TGC could preoccupy SIRP $\alpha$, leading to the saturation of SIRP $\alpha$, then enhancing macrophagemediated phagocytosis of tumor cells [35].

\subsection{Cellular ROS Detection}

The intracellular ROS level was also measured on 4T1 cells after treatment with $\mathrm{m}_{\mathrm{e}}$ TGCT by flow cytometer and CLSM. As revealed in Fig. 4g, the fluorescence signal was nearly detected in the control group regardless of $635 \mathrm{~nm}$ light irradiation, and that of the $\mathrm{Ti}_{3} \mathrm{C}_{2}$ group slightly enhanced, indicating the ROS generation capacity of $\mathrm{Ti}_{3} \mathrm{C}_{2}$ under laser irradiation. The fluorescence signal in $\mathrm{m}_{\mathrm{e}} \mathrm{T}$ group was as strong as that of $\mathrm{Ti}_{3} \mathrm{C}_{2}$ treatment, which could be ascribed to the increased uptake by tumor cells owing to homologous targeting mediated by the cell membrane (Fig. 4a--c). Further enhanced DCF fluorescence was found in the $\mathrm{m}_{\mathrm{e}}$ TG and $\mathrm{m}_{\mathrm{e}}$ TC groups, which was because $\mathrm{m}_{\mathrm{e}} \mathrm{TG}$ could catalyze glucose and $\mathrm{O}_{2}$ into $\mathrm{H}_{2} \mathrm{O}_{2}$, and $\mathrm{m}_{\mathrm{e}} \mathrm{TC}$ could catalyze endogenous $\mathrm{H}_{2} \mathrm{O}_{2}$ into $\mathrm{HClO}$, and $\mathrm{m}_{\mathrm{e}} \mathrm{TGC}$ group exhibited more intensive fluorescence signal than the $\mathrm{m}_{\mathrm{e}} \mathrm{TG}$ and $\mathrm{m}_{\mathrm{e}} \mathrm{TC}$ groups, indicating that the cascaded catalytic reaction could effectively generate ROS. The fluorescence intensities of the $\mathrm{m}_{\mathrm{e}}$ TGCT group were further strengthened, which might be because that the secondary electrons derived from the irradiated $\mathrm{Ti}_{3} \mathrm{C}_{2}$ could be captured by TPZ to further generate hydroxyl radicals by a reductive reaction [54]. Most importantly, the strongest DCF signal was observed in $\mathrm{m}_{\mathrm{e}} \mathrm{TGCT}+\mathrm{L}$ group, suggesting $\mathrm{m}_{\mathrm{e}}$ TGCT could effectively 


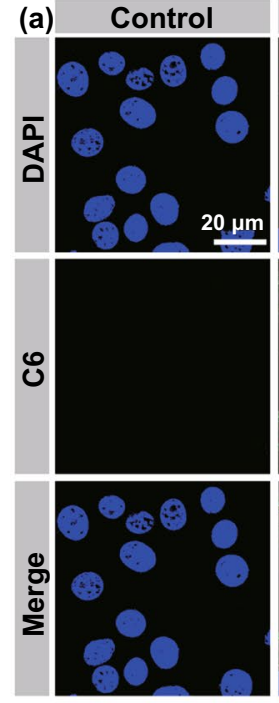

(b)
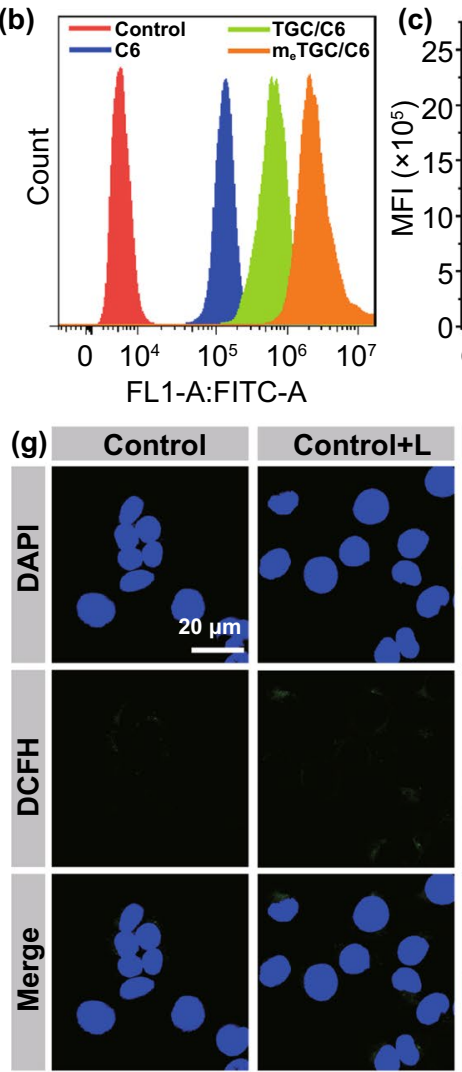

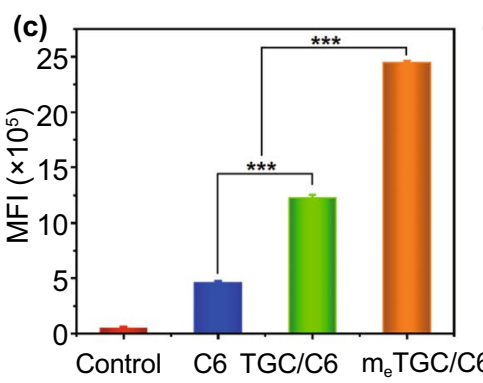

Control C6 TGC/C6 $\mathrm{m}_{\mathrm{e}}^{\mathrm{TGC} / \mathrm{C} 6}$
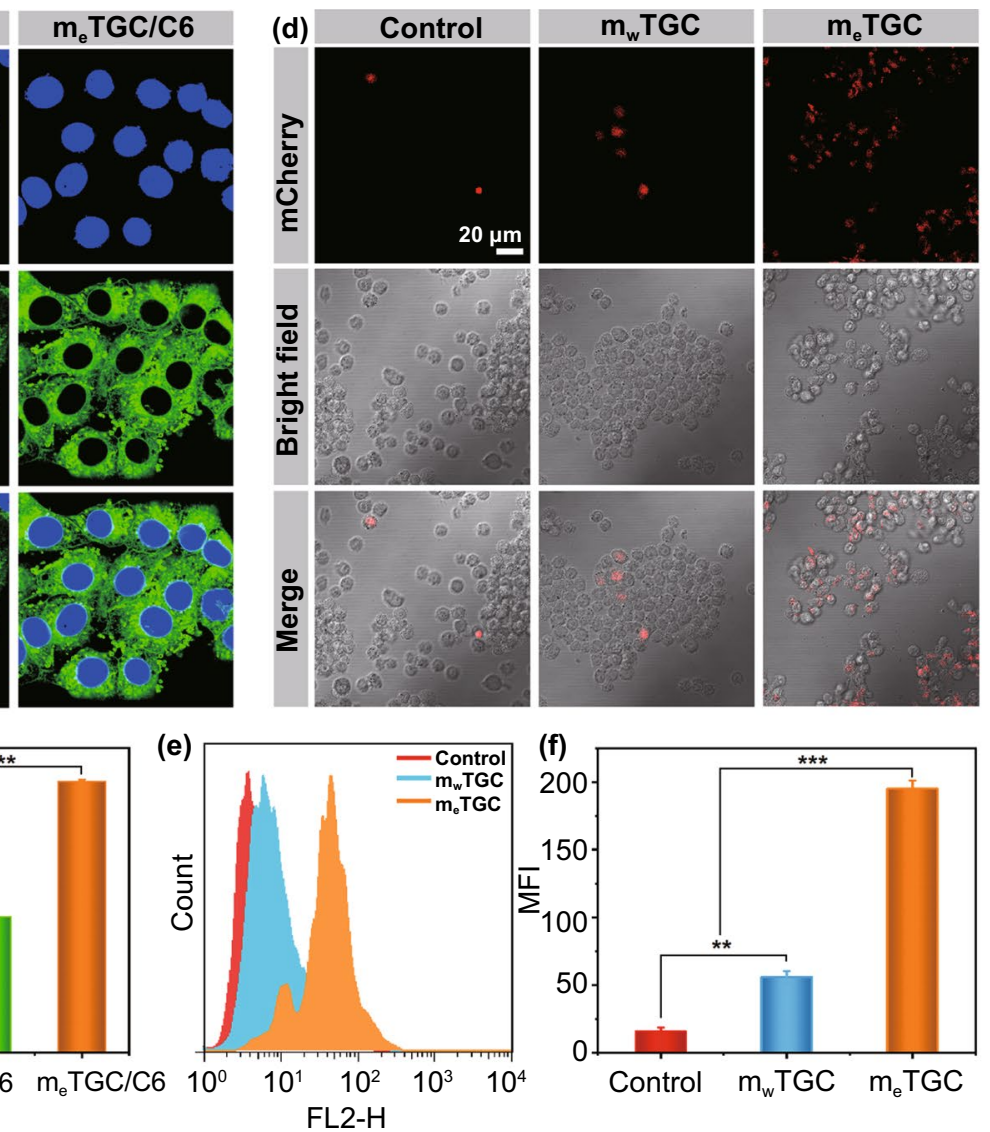

Fig. 4 a CLSM results of 4T1 cells uptake toward TGC/C6 and $\mathrm{m}_{\mathrm{e}} \mathrm{TGC} / \mathrm{C} 6$ at $4 \mathrm{~h}$. b Flow cytometric results and c quantitative flow analysis of 4T1 cells uptake of C6-labeled different formulations. d CLSM results of 4T1 cells were swallowed by macrophages after different treatments with $\mathrm{m}_{\mathrm{w}}$ TGC and $\mathrm{m}_{\mathrm{e}}$ TGC. e Flow histogram analysis and $\mathbf{f}$ quantitative flow analysis of $4 \mathrm{~T} 1$ cells swallowed by macrophages after treatments with $\mathrm{m}_{\mathrm{w}}$ TGC and $\mathrm{m}_{\mathrm{e}}$ TGC. $\mathrm{g}$ CLSM results of intracellular ROS level. ( $* * * p<0.001$, $* * p<0.01, n=3$ )

generate ROS in living cells under $635 \mathrm{~nm}$ light. The results of the flow cytometry also verified that $\mathrm{m}_{\mathrm{e}} \mathrm{TGCT}+\mathrm{L}$ group exhibited the strongest ROS production among all the treatment groups, which was almost 13 -fold higher than that of $\mathrm{m}_{\mathrm{e}} \mathrm{T}$ group (Fig. S16). These results confirmed that $\mathrm{m}_{\mathrm{e}}$ TGCT could generate sufficient ROS via several different 

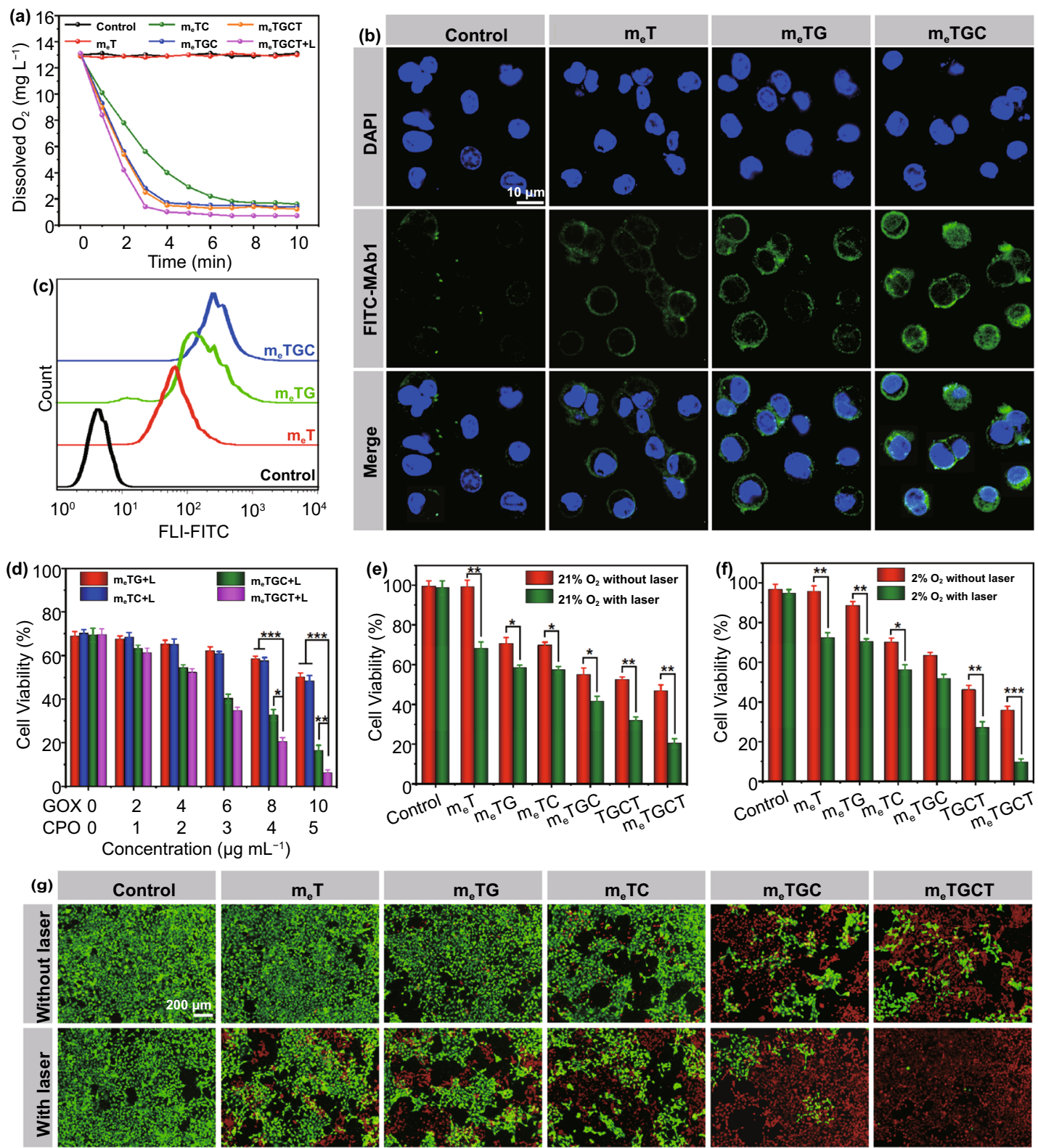

$\mathrm{m}_{\mathrm{e}}$ TGCT

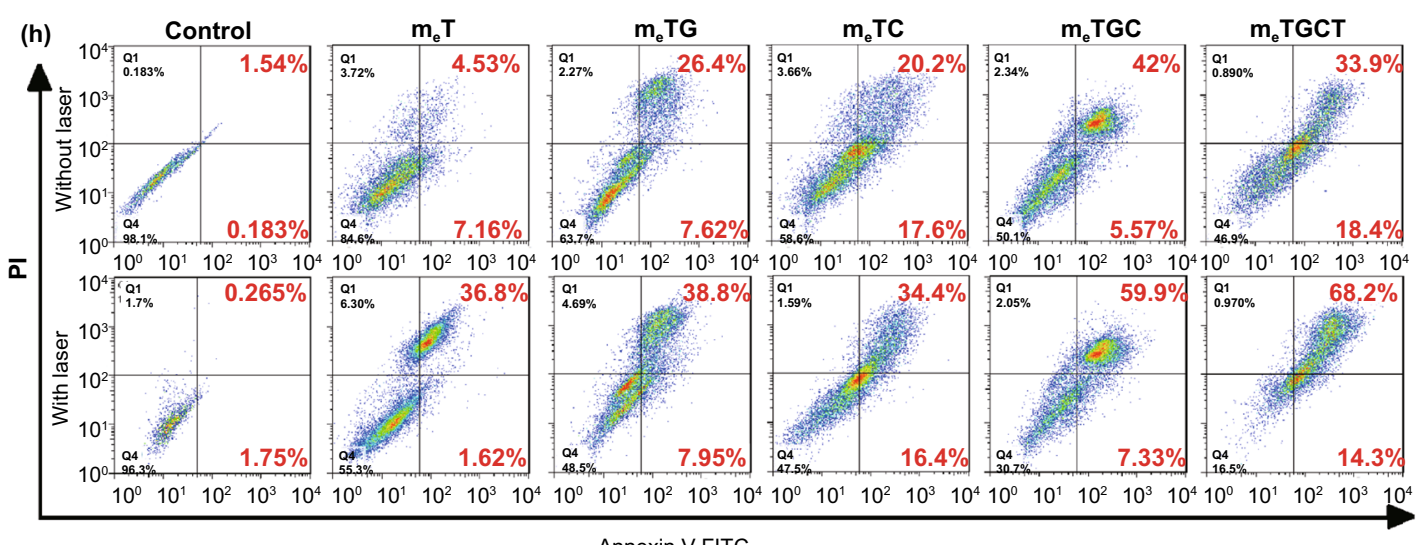

Annexin V-FITC 
\Fig. 5 a Change of dissolved $\mathrm{O}_{2}$ in $4 \mathrm{~T} 1$ cells treated with different formulations. b CLSM images and $\mathbf{c}$ flow histogram of cellular hypoxia of 4T1 cells incubated with different formulations using a hypoxia probe. d Cell viability of $4 \mathrm{~T} 1$ cells treated with $\mathrm{m}_{\mathrm{e}} \mathrm{TG}$, $\mathrm{m}_{\mathrm{e}}$ TC, $\mathrm{m}_{\mathrm{e}}$ TGC, and $\mathrm{m}_{\mathrm{e}}$ TGCT with various GOX/CPO concentrations under $808+635 \mathrm{~nm}$ lasers irradiation. Cell viability of 4T1 cells incubated with various formulations in e $21 \% \mathrm{O}_{2}$ condition and f $2 \% \mathrm{O}_{2}$ condition with/without laser irradiation. $\mathbf{g}$ Live/dead staining images and $\mathbf{h}$ cell apoptosis of $4 \mathrm{~T} 1$ cells after various treatments for $4 \mathrm{~h}(* * * p<0.001, * * p<0.01, * p<0.05, n=5)$

mechanisms, thereby achieving promising overall therapeutic effects in vitro.

\subsection{Intracellular Hypoxia Detection of 4T1 Cells}

The intracellular $\mathrm{O}_{2}$ consumption effects were evaluated by incubating 4T1 cells with different samples and detecting the changes of the dissolved $\mathrm{O}_{2}$ in the DMEM medium. As shown in Fig. 5a, a quick depletion of $\mathrm{O}_{2}$ was found in the $\mathrm{m}_{\mathrm{e}}$ TGC and $\mathrm{m}_{\mathrm{e}}$ TGCT groups, and the most rapid $\mathrm{O}_{2}$ depletion rate was exhibited in the $\mathrm{m}_{\mathrm{e}}$ TGCT group with $635 \mathrm{~nm}$ laser irradiation, indicating that the cascaded-enzyme could increase intracellular $\mathrm{O}_{2}$ consumption. In addition, the cellular hypoxia level was further assessed by CLSM and flow cytometry using a FITC-Mab1 antibody (Fig. S17). It could find that the fluorescence intensities of all groups with $635 \mathrm{~nm}$ light irradiation were significantly higher than those of groups without laser irradiation, attributing to the consumption of $\mathrm{O}_{2}$ caused by the photodynamic effect. Besides, the merely slight green fluorescence of hypoxia-positive signal was found in the $\mathrm{m}_{\mathrm{e}} \mathrm{T}$ group with $635 \mathrm{~nm}$ laser irradiation, attributing to the small amount of $\mathrm{O}_{2}$ consumption caused by PDT effect. 4T1 cells treated with $\mathrm{m}_{\mathrm{e}} \mathrm{TG}$ exhibited enhanced fluorescence intensity, whereas the strongest fluorescence intensity was observed in the $\mathrm{m}_{\mathrm{e}}$ TGC group, which ascribed to the more $\mathrm{O}_{2}$ depletion by cascaded-enzyme (GOX and CPO) and PDT effect of $\mathrm{Ti}_{3} \mathrm{C}_{2}$ (Fig. 5b, c). The aforementioned results indicated that the cascaded-enzyme catalytic reaction could effectively consume cellular $\mathrm{O}_{2}$ level for the potential activation of TPZ in treatment studies.

\subsection{In vitro Antitumor Effects of $m_{\mathrm{e}}$ TGCT}

Before measuring the antitumor efficiency of cascadedenzyme nanoreactor, we estimated the real-time temperature variation in cells with $808 \mathrm{~nm}$ light irradiation. As clarified in Fig. S18, the temperature in both of experiment groups showed rapid temperature rise, while control group merely rose to $29.6{ }^{\circ} \mathrm{C}$ within $3 \mathrm{~min}$ of $808 \mathrm{~nm}$ laser irradiation. Particularly, the temperature of $\mathrm{m}_{\mathrm{e}} \mathrm{TGC}$ group reached to mild hypothermia condition $\left(44.6^{\circ} \mathrm{C}\right)$, which was beneficial to improve the EDT and PDT effects. Afterward, the remarkable capacities of the cascaded catalysis and the therapeutic effects of $\mathrm{m}_{\mathrm{e}}$ TGCT were evaluated by MTT assays in vitro. As displayed in Fig. S19a, b, almost no distinct cytotoxicity of $\mathrm{Ti}_{3} \mathrm{C}_{2}$ and $\mathrm{m}_{\mathrm{e}} \mathrm{T}$ indicated their satisfactory biocompatibility. The cell viability decreased with the increment concentration of $\mathrm{m}_{\mathrm{e}} \mathrm{T}$ under $808+635 \mathrm{~nm}$ lasers irradiation, indicating the phototherapy effects of $\mathrm{m}_{\mathrm{e}} \mathrm{T}$. The therapeutic effects of $\mathrm{m}_{\mathrm{e}} \mathrm{TG}, \mathrm{m}_{\mathrm{e}} \mathrm{TC}, \mathrm{m}_{\mathrm{e}} \mathrm{TGC}$, and $\mathrm{m}_{\mathrm{e}}$ TGCT with various concentrations are shown in Fig. 5d, and $\mathrm{m}_{\mathrm{e}}$ TGCT displayed the highest cytotoxicity against $4 \mathrm{~T} 1$ cells comparing to other groups, owing to the cancer cell membrane coating prompting more cellular uptake of TGCT, and the cascaded catalytic reaction achieving efficient EDT, as well as hypoxic-activation of TPZ for chemotherapy. Considering that cascaded-enzyme nanoreactor could induce the tumor cell deoxygenation, we evaluated the therapeutic effects of $\mathrm{m}_{\mathrm{e}}$ TGCT in normoxic or in hypoxic environments with/without $808+635 \mathrm{~nm}$ laser irradiation. Firstly, the cytotoxicity of chemotherapeutic effects on $4 \mathrm{~T} 1$ cells is evaluated in Fig. S19c, free TPZ exhibited almost no cytotoxicity on 4T1 cells owing to the unactivated status of TPZ in normoxic environment. Besides, Fig. 5e, f shows that cell viability of TPZ free groups $\left(\mathrm{m}_{\mathrm{e}} \mathrm{T}, \mathrm{m}_{\mathrm{e}} \mathrm{TG}, \mathrm{m}_{\mathrm{e}} \mathrm{TC}\right.$, and $\left.\mathrm{m}_{\mathrm{e}} \mathrm{TGC}\right)$ in hypoxic environment was similar to that in normoxic environment, while the anticancer effects of the $\mathrm{m}_{\mathrm{e}}$ TGCT and TGCT groups in hypoxic environment were enhanced compared to those in the normoxic environment, which could be attributed to the deoxygenation-activated chemotherapy effect of TPZ [27]. To statistically confirm the combination effects of PTT, PDT, EDT and chemotherapy on 4T1 cells inhibition, the combination index (CI) was calculated on the basis of the Chou-Talalay assay [55]. The 50\% inhibition concentration $\left(\mathrm{IC}_{50}\right)$ of TPZ group in hypoxia environment was $26.92 \mu \mathrm{g} \mathrm{mL}^{-1}$, and the $\mathrm{IC}_{50}$ of $\mathrm{m}_{\mathrm{e}} \mathrm{TGC}$ under laser irradiation group was $51.21 \mu \mathrm{g} \mathrm{mL}^{-1}$. The $\mathrm{IC}_{50}$ of $\mathrm{m}_{\mathrm{e}}$ TGCT under laser irradiation and hypoxia environment was $19.27 \mu \mathrm{g} \mathrm{mL}^{-1}$, and the CI was calculated as 0.824 , indicating there were synergistic effects between phototherapy and chemotherapy. In addition, we further measured the therapeutic effects of $m_{e}$ TGCT in media with high glucose level 
or low glucose level (Fig. S19d). Compared with the high cell viability of $\mathrm{m}_{\mathrm{e}}$ TG group in high glucose level media, the $\mathrm{m}_{\mathrm{e}}$ TGCT group exhibited the enhanced cell cytotoxicity on account of the cascaded EDT effects. Besides, in low glucose level media, the cell viability of the $\mathrm{m}_{\mathrm{e}}$ TGCT group also reached $12.5 \%$ at $24 \mathrm{~h}$ under laser irradiation, owing to EDT effect and cell starvation induced by the complete glucose decomposition, indicating the exclusive effect of the $\mathrm{m}_{\mathrm{e}}$ TGCT nanoreactor in tumor cell growth suppression with or without glucose supply. These results strongly indicated that the combined phototherapy/EDT/chemotherapy with $\mathrm{m}_{\mathrm{e}}$ TGCT treatment under laser irradiation could effectively kill tumor cells.

On purpose of evaluating visually anticancer effects of $\mathrm{m}_{\mathrm{e}}$ TGCT in vitro, Calcein-AM/PI staining fluorescence imaging was further conducted to observe the cell live/ dead states (Fig. 5g). Briefly, a small number of cells turned into orange or red (dead) in the $\mathrm{m}_{\mathrm{e}} \mathrm{TG}$ and $\mathrm{m}_{\mathrm{e}} \mathrm{TC}$ groups, indicating $\mathrm{m}_{\mathrm{e}} \mathrm{TG}$ and $\mathrm{m}_{\mathrm{e}} \mathrm{TC}$ could induce slight cells death. Under laser irradiation, the number of red cells increased, ascribing to the phototherapy effect of $\mathrm{Ti}_{3} \mathrm{C}_{2}$. Specially, almost all cells were stained red in $\mathrm{m}_{\mathrm{e}}$ TGCT group with laser irradiation, which further confirmed the best anticancer efficacy of $\mathrm{m}_{\mathrm{e}}$ TGCT treatment under laser irradiation toward $4 \mathrm{~T} 1$ cells. In addition, the apoptosis experiment confirmed similar results (Fig. 5h). The proportions of early and late apoptosis cells were $11.69 \%, 34.02 \%, 37.8 \%$, and $47.57 \%$ after treatment with $\mathrm{m}_{\mathrm{e}} \mathrm{T}, \mathrm{m}_{\mathrm{e}} \mathrm{TG}, \mathrm{m}_{\mathrm{e}} \mathrm{TC}$, and $\mathrm{m}_{\mathrm{e}} \mathrm{TGC}$, respectively, which increased to $38.42 \%, 46.75 \%, 50.8 \%$, and $67.23 \%$ after being exposed to laser irradiation, respectively, while that of $\mathrm{m}_{\mathrm{e}}$ TGCT with laser irradiation (82.5\%) was far higher than the above groups, demonstrating definite superiority for tumor therapy comparing to single EDT, phototherapy or chemotherapy. Therefore, the combination of tumor phototherapy, EDT and chemotherapy was a safe and effective synergistic strategy for tumor treatment.

\subsection{In vivo Fluorescence Imaging}

Inspired by the excellent capacity of homologous targeting in vitro, the tumor targeting and accumulation performance of $\mathrm{m}_{\mathrm{e}}$ TGCT were determined in vivo. As shown in Fig. 6a, $\mathrm{b}$, the $\mathrm{m}_{\mathrm{e}} \mathrm{TGC} / \mathrm{Cy} 5.5$ fluorescence intensity increased persistently and achieved a peak at $24 \mathrm{~h}$. Although the fluorescence intensity decreased gradually after $72 \mathrm{~h}$, it was still detected at $120 \mathrm{~h}$, demonstrating the continued retention of $\mathrm{m}_{\mathrm{e}}$ TGC in tumor tissue. $\mathrm{m}_{\mathrm{w}}$ TGC/Cy5.5 group showed similar fluorescence changes within $24 \mathrm{~h}$, while the fluorescence signal decreased quickly after that. The dramatic distinction was attributed to the enhanced immune escape and long circulation effect of $\mathrm{m}_{\mathrm{e}}$ TGC due to high-expressed CD47. In contrast, the fluorescence signal of TGC/Cy5.5 was weaker at the tumor site and faded away quickly after $12 \mathrm{~h}$ postinjection. Moreover, the fluorescence intensity of $\mathrm{m}_{\mathrm{e}} \mathrm{TGC} /$ Cy5.5 was always 7 to 34 times as high as that of TGC/ Cy5.5 at different time intervals, which clearly exhibited the long-term tumor duration property. Besides, all tumors and organs were obtained after 24 or $120 \mathrm{~h}$ post-injection (Fig. 6c, e), semiquantitative analysis of the fluorescence intensity is shown in Fig. 6d, f. In the TGC/Cy5.5 group, Cy5.5 mainly accumulated in liver and kidney after $24 \mathrm{~h}$, while that of $\mathrm{m}_{\mathrm{e}} \mathrm{TGC} / \mathrm{Cy} 5.5$ group was obviously observed in tumor, 15.6-fold as high as that of TGC/Cy5.5 group, exhibiting the enhanced tumor accumulation and prolonged blood circulation after coating with the homologous tumor cell membrane with high CD47 expression. Such long circulation time would effectively enhance the therapeutic efficiency of nanoreactor. Most importantly, this highly specific tumor recognition capacity of $\mathrm{m}_{\mathrm{e}}$ TGC could significantly strengthen the therapeutic effects, as well as reduce the side effects.

\subsection{In vivo Photothermal Imaging and Tumor Hypoxia Detection}

To evaluate the in vivo photothermal effect, the temperature changes of the tumor region were detected (Figs. $6 \mathrm{~g}$ and S20). In control group, the temperature showed negligible change within $2 \mathrm{~min}$, while that in $\mathrm{m}_{\mathrm{e}}$ TGC treated group rapidly rose from 36.3 to $46.4{ }^{\circ} \mathrm{C}$ within $2 \mathrm{~min}$, which could provide a mild hypothermia condition for the enhancement of EDT and PDT effects.

After proving the tumor accumulation of $\mathrm{m}_{\mathrm{e}}$ TGCT, we explored the intratumoral hypoxia status after $48 \mathrm{~h}$ intravenous administration of $\mathrm{m}_{\mathrm{e}}$ TGCT in vivo. As displayed in Fig. S21, there was almost no fluorescence signal of hypoxia (green) in PBS and $\mathrm{m}_{\mathrm{e}} \mathrm{T}$ groups, while the increased fluorescence intensity in the treatment groups with GOX indicated the aggravation of tumor hypoxia status due to $\mathrm{O}_{2}$ consumption after GOX catalyzing the glucose and $\mathrm{O}_{2}$. Besides, the 


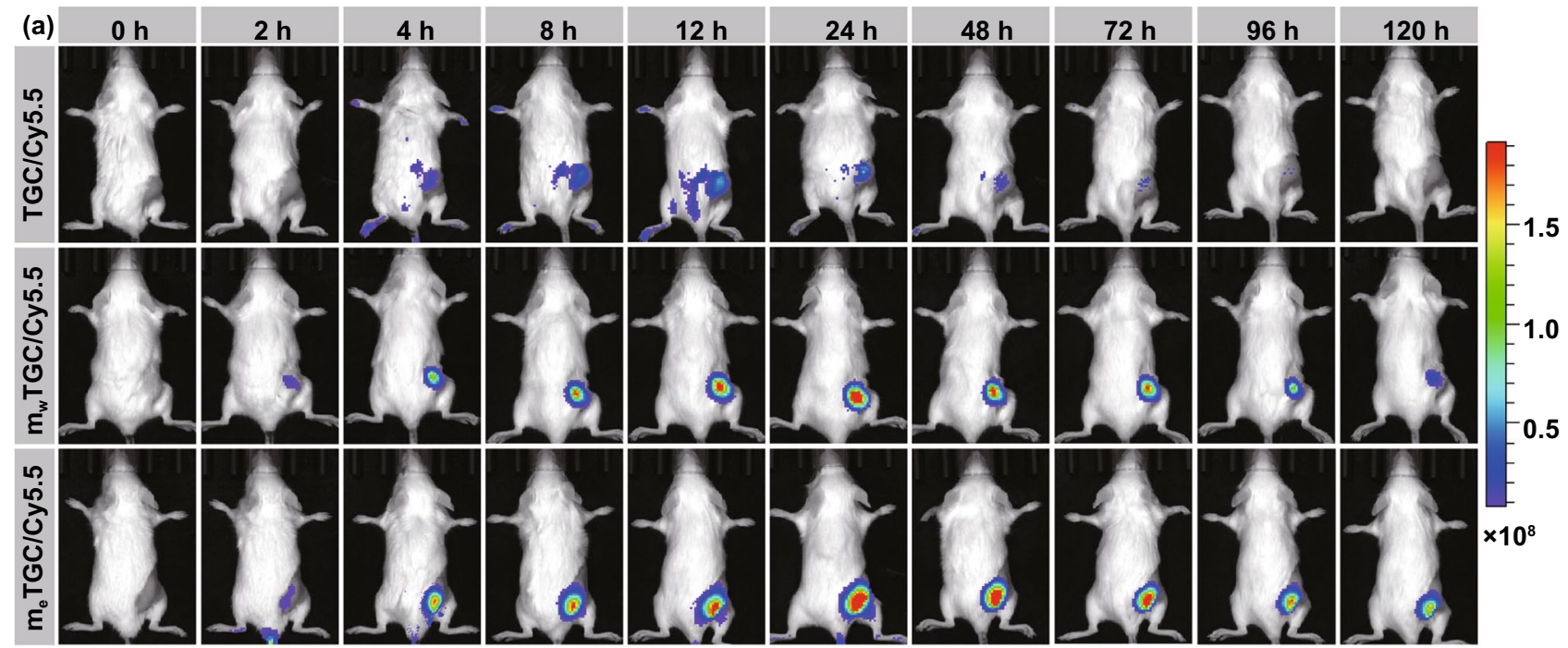

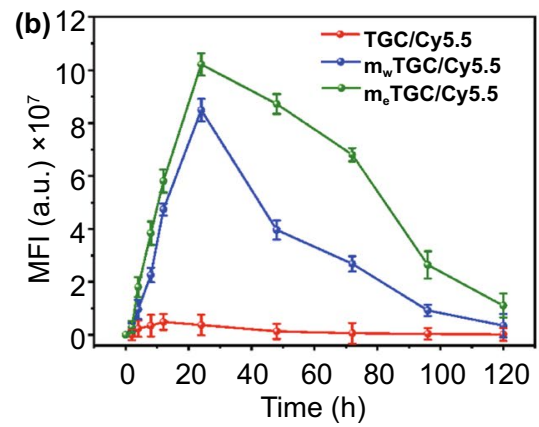

(c)

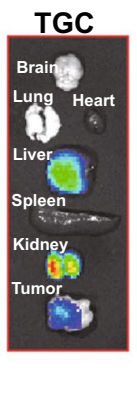

(e)

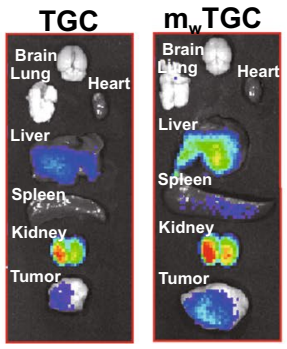

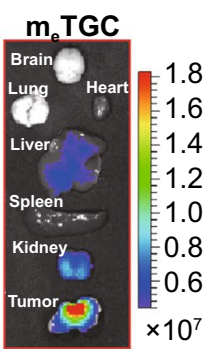

(f)

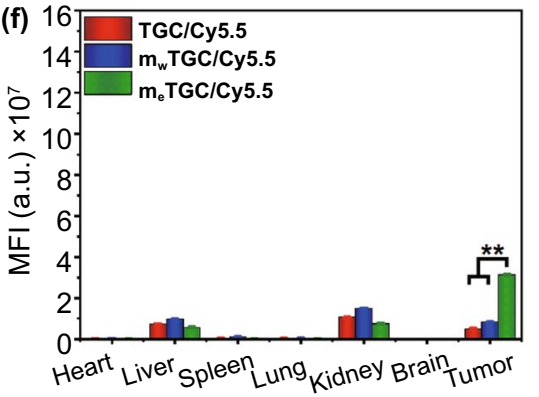

(d) $1 6 \longdiv { \text { TGC/Cy5.5 } }$
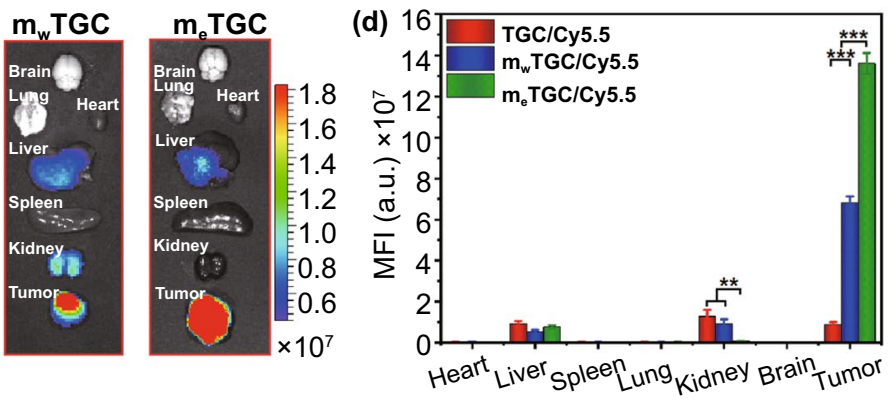

(g)

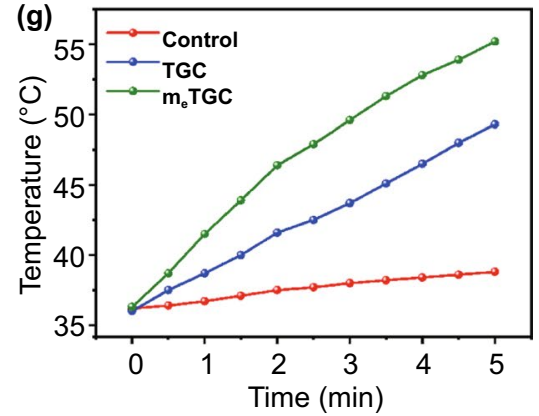

Fig. 6 a Biodistribution of TGC/Cy5.5, $\mathrm{m}_{\mathrm{w}} \mathrm{TGC} / \mathrm{Cy} 5.5$, and $\mathrm{m}_{\mathrm{e}} \mathrm{TGC} / \mathrm{Cy} 5.5$ in $4 \mathrm{~T} 1$ tumor-bearing mice. b Corresponding average fluorescence intensity based on a. Fluorescence imaging of organs and tumor $\mathbf{c}$ at $24 \mathrm{~h}$ and $\mathbf{e}$ at $120 \mathrm{~h}$ post-injection. Corresponding average fluorescence intensity of major organs and tumor at $24 \mathrm{~h} \mathrm{~d}$ based on $\mathbf{c}$ and $120 \mathrm{~h} \mathrm{f} \mathrm{based} \mathrm{on} \mathrm{e.} \mathbf{g}$ Temperature changes of tumor region under $808 \mathrm{~nm}$ light $\left(1.5 \mathrm{~W} \mathrm{~cm}^{-2}\right)$ within $5 \min (* * * p<0.001, * * p<0.01, n=3)$

treatment groups with GOX and CPO showed the greatly enhanced fluorescence intensity, which was ascribed to the cascaded EDT effect increasing $\mathrm{O}_{2}$ consumption. After laser irradiation, the intratumoral $\mathrm{O}_{2}$ level was further exhausted due to PDT and EDT effects, leading to the enhanced tumor hypoxia. Such an $\mathrm{O}_{2}$ consumption dynamic in tumor would be conducive to activate chemotherapeutic effect of TPZ for the enhanced antitumor efficiency.

\subsection{In vivo Antitumor Therapy}

Finally, 4T1 tumor-bearing me systemic antitumor activity of $\mathrm{m}_{\mathrm{e}}$ TGCT. The therapy process and therapeutic effects of $\mathrm{m}_{\mathrm{e}}$ TGCT are shown in Fig. 7a, b. The tumor sizes in control and $\mathrm{m}_{\mathrm{e}} \mathrm{T}$ groups increased quickly, and the slight tumor growth was inhibited by $\mathrm{m}_{\mathrm{e}} \mathrm{TG}$ via tumor starvation. The $\mathrm{m}_{\mathrm{e}}$ TGC exhibited moderate tumor growth inhibition with V/ 
$\mathrm{V}_{0}$ value of 8.1 on day 31 , due to the generation of plentiful $\mathrm{HClO}$ caused by cascaded-enzyme reaction. Comparing to TGCT and $\mathrm{m}_{\mathrm{e}}$ TGC groups, the mice treated with $\mathrm{m}_{\mathrm{e}}$ TGCT presented a slow growth of tumors and the final $\mathrm{V} / \mathrm{V}_{0}$ was 4.5, due to the efficient homologous targeting capacities and starvation/EDT/chemotherapy effects. Besides, under laser irradiation, $\mathrm{m}_{\mathrm{e}}$ TGCT exhibited the strongest therapeutic outcomes $(\mathrm{V} / \mathrm{V} 0=0.003)$ among all the groups through the tumor targeting phototherapy and EDT magnified chemotherapy, indicating that the biomimetic cascaded-enzyme nanoreactor offered an optimal strategy for tumor treatment.
Similarly, the weight (Fig. 7d) and photographs (Fig. 7e) of tumors harvested from the mice on day 31 further attested the superior tumor suppression effect of $\mathrm{m}_{\mathrm{e}} \mathrm{TGCT}$ with laser irradiation. It was noted that there were two mice treated with $\mathrm{m}_{\mathrm{e}}$ TGCT and laser irradiation got completely tumor remission at the end of the treatment. Meanwhile, compared to the control group where all mice died, the mice of $\mathrm{m}_{\mathrm{e}}$ TGCT + laser treatment all lived for 31 days and there were two mice got complete elimination of tumor until they were dissected, demonstrating this nanoreactor could extend the survival period of tumor-bearing mice (Fig. S22). And

(a)
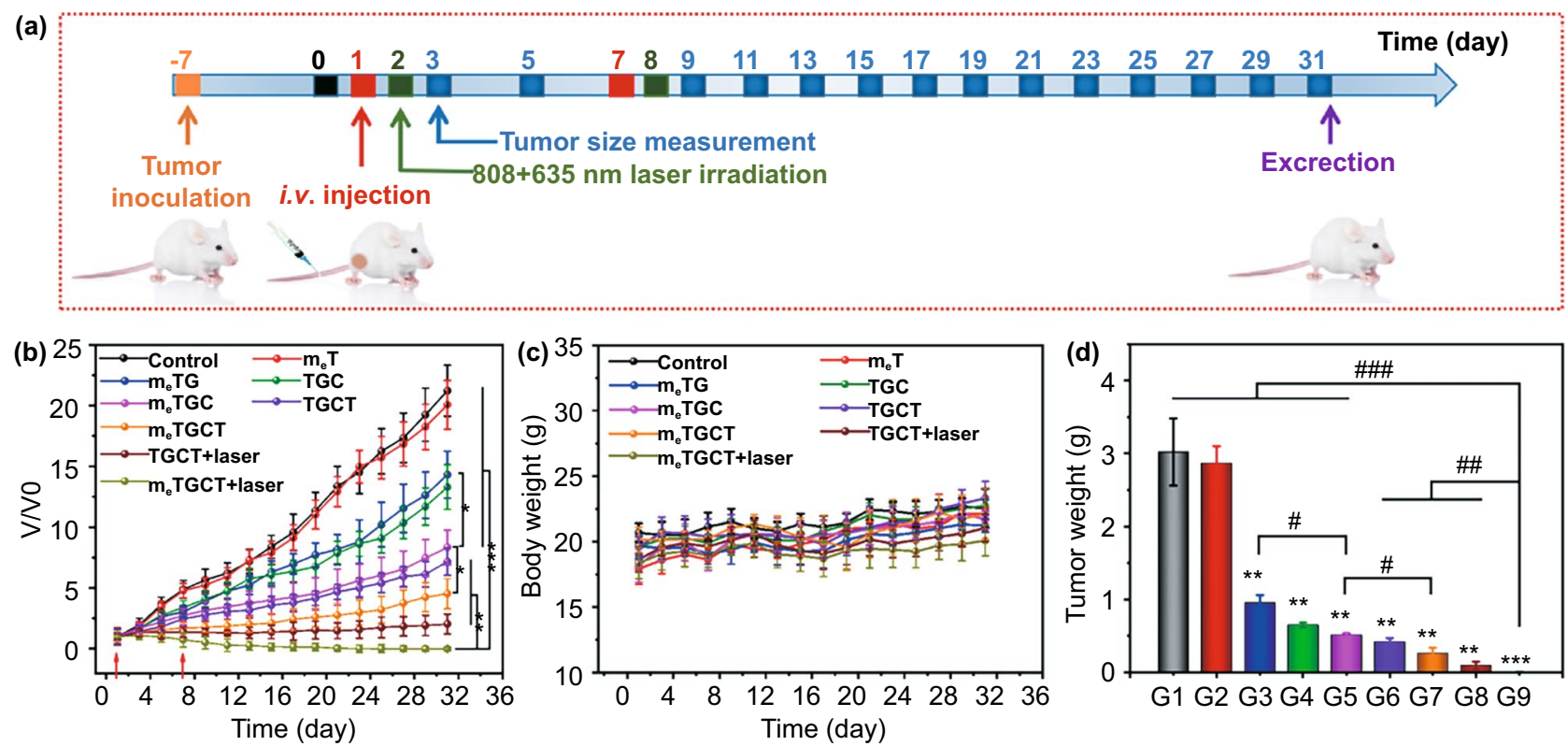

(e)
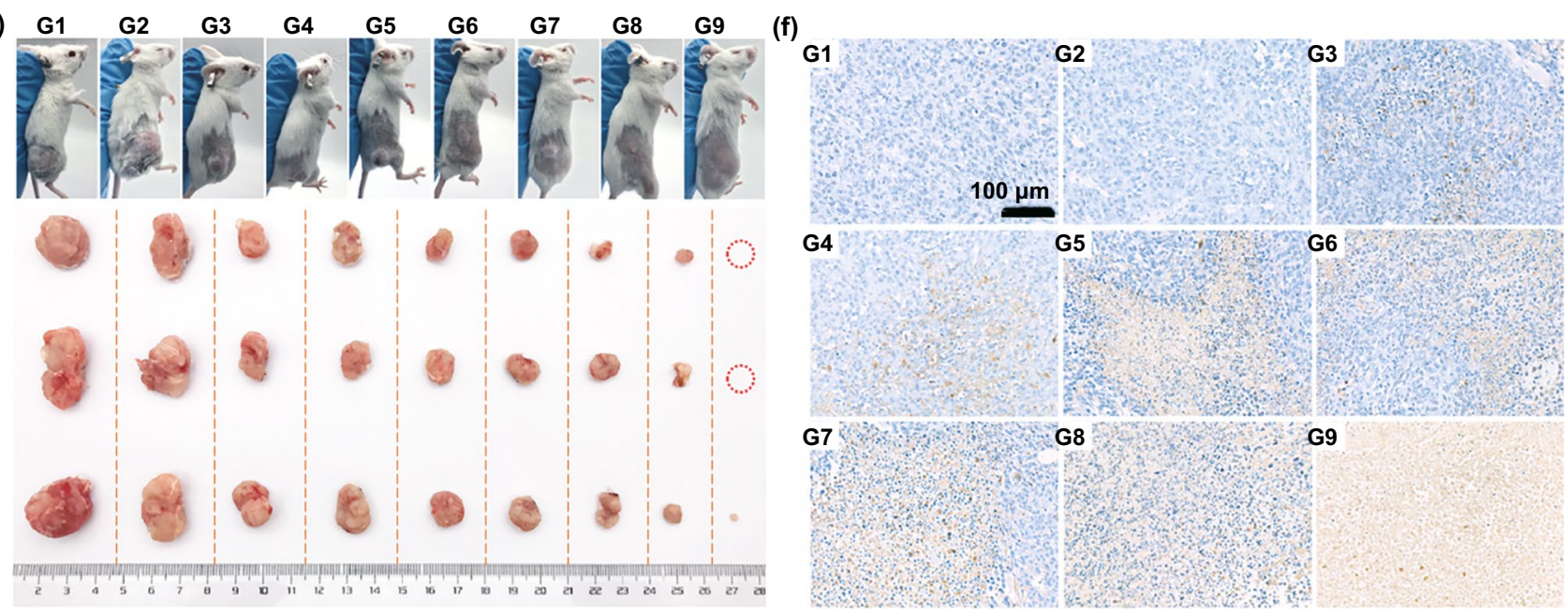

Fig. 7 a Therapy process of $\mathrm{m}_{\mathrm{e}}$ TGCT. b The variation in V/V0 in different groups. $\mathbf{c}$ Variations in body weight and $\mathbf{d}$ tumor weight during various treatments. e Photographs of mice and tumor tissues on day 31. f TUNEL staining of tumors were harvested from the mice of different treatments. (G1) Control, (G2) $\mathrm{m}_{\mathrm{e}} \mathrm{T},(\mathrm{G} 3) \mathrm{m}_{\mathrm{e}} \mathrm{TG}$, (G4) TGC, (G5) $\mathrm{m}_{\mathrm{e}} \mathrm{TGC}$, (G6) TGCT, (G7) $\mathrm{m}_{\mathrm{e}} \mathrm{TGCT}$, (G8) TGCT+laser, (G9) m $\mathrm{e}$ TGCT+laser $\left(* * * p<0.001, * * p<0.01\right.$ and $* p<0.05$ as contrast with Control group, $\left.{ }^{\# \#} p<0.001,{ }^{\# \#} p<0.01,{ }^{\#} p<0.05, n=5\right)$ 
the body weights of the mice showed no distinct variations within 31 days (Fig. 7c), indicating the low systemic toxicity of $\mathrm{m}_{\mathrm{e}}$ TGCT.

In addition, the major physiological and biochemical parameters in serum of the mice after treatments were also evaluated. As illustrated in Fig. S23, liver function (ALT, AST, ALB, ALP, TP, $\gamma$-GT), kidney function indexes (BUN, $\mathrm{CR}$ ) and GLU level were in the normal range after treatment with $\mathrm{m}_{\mathrm{e}}$ TGCT, confirming the biosafety of the cascadedenzyme nanoreactor. Furthermore, H\&E staining analysis of the main organs also demonstrated the biosafety of $\mathrm{m}_{\mathrm{e}}$ TGCT during the treatment (Fig. S24). The results indicated that $\mathrm{m}_{\mathrm{e}}$ TGCT could significantly eliminate the tumor with satisfying biosecurity.

To further evaluate the antitumor effects of $\mathrm{m}_{\mathrm{e}}$ TGCT, we dissected the tumors of all groups for terminal transferase dUTP (TUNEL) apoptosis staining (Fig. 7f), H\&E and Ki67 antigen results (Figs. S25 and S26), which all suggested that treatment with $\mathrm{m}_{\mathrm{e}}$ TGCT under laser irradiation caused the most significant cell damage and apoptosis in all groups. The superiority of $\mathrm{m}_{\mathrm{e}}$ TGCT treatment further demonstrated the advantages of combined therapy on the basis of cascadedenzyme nanoreactor-mediated tumor phototherapy, enzyme dynamic therapy and the subsequent deoxygenation-activated chemotherapy.

\section{Conclusions}

Summarily, an intelligent bionic cascaded-enzyme nanoreactor $\left(\mathrm{m}_{\mathrm{e}} \mathrm{TGCT}\right)$ was performed to achieve amplified antitumor efficiency via phototherapy/enzyme dynamic therapy/chemotherapy. In vitro and in vivo results exhibited that $\mathrm{m}_{\mathrm{e}}$ TGCT nanoreactor was stable during long blood circulation and was able to achieve immune escape and homologous targeting capacities. Besides, the cascaded-enzyme nanoreactor could readily consume glucose and molecular $\mathrm{O}_{2}$ at tumor sites under laser irradiation to achieve tumor phototherapy/enzyme dynamic therapy and then created a more hypoxic TME to motivate chemotherapy. Significantly, this bionic cascadedenzyme nanoreactor provided an innovative insight for the development of complementary patterns for efficient antitumor therapy.
Acknowledgements This work was supported by the National Natural Science Foundation of China (51773231), Shenzhen Science and Technology Project (JCYJ20190807160801664) and the Project of Key Laboratory of Sensing Technology and Biomedical Instruments of Guangdong Province (2011A060901013).

Funding Open access funding provided by Shanghai Jiao Tong University.

Open Access This article is licensed under a Creative Commons Attribution 4.0 International License, which permits use, sharing, adaptation, distribution and reproduction in any medium or format, as long as you give appropriate credit to the original author(s) and the source, provide a link to the Creative Commons licence, and indicate if changes were made. The images or other third party material in this article are included in the article's Creative Commons licence, unless indicated otherwise in a credit line to the material. If material is not included in the article's Creative Commons licence and your intended use is not permitted by statutory regulation or exceeds the permitted use, you will need to obtain permission directly from the copyright holder. To view a copy of this licence, visit http://creativecommons.org/licenses/by/4.0/.

Supplementary Information The online version contains supplementary material available at https://doi.org/10.1007/ s40820-021-00761-w.

\section{References}

1. R.L. Siegel, K.D. Miller, H.E. Fuchs, A. Jemal, Cancer statistics, 2021. Ca-Cancer J. Clin. 71, 7-33 (2021). https://doi.org/ 10.3322/caac. 21654

2. A. Bergamo, G. Sava, Linking the future of anticancer metalcomplexes to the therapy of tumour metastases. Chem. Soc. Rev. 44, 8818-8835 (2015). https://doi.org/10.1039/c5cs0 $0134 \mathrm{j}$

3. Y.P. Wang, W.Q. Gao, X.Y. Shi, J.J. Ding, W. Liu et al., Chemotherapy drugs induce pyroptosis through caspase-3 cleavage of a gasdermin. Nature (2017). https://doi.org/10.1038/natur e22393

4. Y. Shamay, J. Shah, M. Isik, A. Mizrachi, J. Leibold et al., Quantitative self-assembly prediction yields targeted nanomedicines. Nat. Mater. 17, 361 (2018). https://doi.org/10. 1038/s41563-017-0007-z

5. Q. Wu, Z.G. He, X. Wang, Q. Zhang, Q.C. Wei et al., Cascade enzymes within self-assembled hybrid nanogel mimicked neutrophil lysosomes for singlet oxygen elevated cancer therapy. Nat. Commun. 10, 240 (2019). https://doi.org/10.1038/ s41467-018-08234-2

6. Q. Zhang, J.J. Wu, J.J. Wang, X. Wang, C. Wu et al., A neutrophil-inspired supramolecular nanogel for 
magnetocaloric-enzymatic tandem therapy. Angew Chem. Int. Ed. 59, 3732-3738 (2020). https://doi.org/10.1002/anie. 201915118

7. C. Gorrini, I.S. Harris, T.W. Mak, Modulation of oxidative stress as an anticancer strategy. Nat. Rev. Drug Discov. 12, 931-947 (2013). https://doi.org/10.1038/nrd4002

8. C. Wang, J.Q. Wang, X.D. Zhang, S.J. Yu, D. Wen et al., In situ formed reactive oxygen species-responsive scaffold with gemcitabine and checkpoint inhibitor for combination therapy. Sci. Transl. Med. (2018). https://doi.org/10.1126/scitr anslmed.aan3682

9. Z.J. Zhou, J.B. Song, R. Tian, Z. Yang, G.C. Yu et al., Activatable singlet oxygen generation from lipid hydroperoxide nanoparticles for cancer therapy. Angew. Chem. Int. Ed. 56, 6492-6496 (2017). https://doi.org/10.1002/anie.201701181

10. D. Trachootham, J. Alexandre, P. Huang, Targeting cancer cells by ros-mediated mechanisms: a radical therapeutic approach? Nat. Rev. Drug Discov. 8, 579-591 (2009). https:// doi.org/10.1038/nrd2803

11. G. Chen, Y.Y. Yang, Q. Xu, M.J. Ling, H.M. Lin et al., Selfamplification of tumor oxidative stress with degradable metallic complexes for synergistic cascade tumor therapy. Nano Lett. 20, 8141-8150 (2020). https://doi.org/10.1021/acs.nanol ett.0c03127

12. B.M. Babior, C. Takeuchi, J. Ruedi, A. Gutierrez, P. Wentworth, Investigating antibody-catalyzed ozone generation by human neutrophils. Proc. Natl. Acad. Sci. USA 100, 30313034 (2003). https://doi.org/10.1073/pnas.0530251100

13. R.J. Reiter, Oxidative processes and antioxidative defensemechanisms in the aging brain. Faseb J. 9, 526-533 (1995)

14. S. Colonna, N. Gaggero, C. Richelmi, P. Pasta, Recent biotechnological developments in the use of peroxidases. Trends Biotechnol. 17, 163-168 (1999). https://doi.org/10. 1016/S0167-7799(98)01288-8

15. E.J. Allain, L.P. Hager, L. Deng, E.N. Jacobsen, Highly enantioselective epoxidation of disubstituted alkenes with hydrogen-peroxide catalyzed by chloroperoxidase. J. Am. Chem. Soc. 115, 4415-4416 (1993). https://doi.org/10.1021/ Ja00063a091

16. R. Renirie, C. Pierlot, J.M. Aubry, A.F. Hartog, H.E. Schoemaker et al., Vanadium chloroperoxidase as a catalyst for hydrogen peroxide disproportionation to singlet oxygen in mildly acidic aqueous environment. Adv. Synth. Catal (2003). https://doi.org/10.1002/adsc.200303008

17. C. Zhang, L. Zhang, W. Wu, F. Gao, R.Q. Li et al., Artificial super neutrophils for inflammation targeting and hclo generation against tumors and infections. Adv. Mater. 31, 1901179 (2019). https://doi.org/10.1002/Adma.201901179

18. O. Soehnlein, S. Steffens, A. Hidalgo, C. Weber, Neutrophils as protagonists and targets in chronic inflammation. Nat. Rev. Immunol. 17, 248-261 (2017). https://doi.org/10.1038/nri. 2017.10

19. D. Roos, C.C. Winterbourn, Immunology - lethal weapons. Science 296, 669-671 (2002). https://doi.org/10.1126/scien ce. 1071271
20. Y. Liu, W.H. Zhang, Y.Y. Cao, Y. Liu, S. Bergmeier et al., Small compound inhibitors of basal glucose transport inhibit cell proliferation and induce apoptosis in cancer cells via glucose-deprivation-like mechanisms. Cancer Lett. 298, 176-185 (2010). https://doi.org/10.1016/j.canlet.2010.07.002

21. S.M. Kim, S.G. Roy, B. Chen, T.M. Nguyen, R.J. McMonigle et al., Targeting cancer metabolism by simultaneously disrupting parallel nutrient access pathways. J. Clin. Invest. 126, 4088-4102 (2016). https://doi.org/10.1172/JCI87148

22. H. Cheng, X.Y. Jiang, R.R. Zheng, S.J. Zuo, L.P. Zhao et al., A biomimetic cascade nanoreactor for tumor targeted starvation therapy-amplified chemotherapy. Biomaterials 195, 75-85 (2019). https://doi.org/10.1016/j.biomaterials.2019.01.003

23. W.P. Fan, N. Lu, P. Huang, Y. Liu, Z. Yang et al., Glucoseresponsive sequential generation of hydrogen peroxide and nitric oxide for synergistic cancer starving-like/gas therapy. Angew. Chem. Int. Ed. 56, 1229-1233 (2017). https://doi.org/ 10.1002/anie.201610682

24. C. Zhang, D.L. Ni, Y.Y. Liu, H.L. Yao, W.B. Bu et al., Magnesium silicide nanoparticles as a deoxygenation agent for cancer starvation therapy. Nat. Nanotechnol. 12, 378-386 (2017). https://doi.org/10.1038/Nnano.2016.280

25. J.J. Liu, Q. Chen, L.Z. Feng, Z. Liu, Nanomedicine for tumor microenvironment modulation and cancer treatment enhancement. Nano Today 21, 55-73 (2018). https://doi.org/10.1016/j. nantod.2018.06.008

26. Y.C. Ma, Y.Y. Zhao, N.K. Bejjanki, X.F. Tang, W. Jiang et al., Nanoclustered cascaded enzymes for targeted tumor starvation and deoxygenation-activated chemotherapy without systemic toxicity. ACS Nano 13, 8890-8902 (2019). https://doi.org/10. 1021/acsnano.9b02466

27. J. Chen, L. Liu, S.M. Motevalli, X.L. Wu, X.H. Yang et al., Light-triggered retention and cascaded therapy of albuminbased theranostic nanomedicines to alleviate tumor adaptive treatment tolerance. Adv. Funct. Mater. 28, 1707291 (2018). https://doi.org/10.1002/Adfm.201707291

28. T.C. Qin, Z.G. Wang, Y.Q. Wang, F. Besenbacher, M. Otyepka et al., Recent progress in emerging two-dimensional transition metal carbides. Nano-Micro Lett. 13, 183 (2021). https://doi. org/10.1007/s40820-021-00710-7

29. W.Q. Qian, S.W. Xu, X.M. Zhang, C.B. Li, W.Y. Yang et al., Differences and similarities of photocatalysis and electrocatalysis in two-dimensional nanomaterials: strategies, traps, applications and challenges. Nano-Micro Lett. (2021). https:// doi.org/10.1007/s40820-021-00681-9

30. D. Wang, B. Xue, T.Y. Ohulchanskyy, Y.B. Liu, A. Yakovliev et al., Inhibiting tumor oxygen metabolism and simultaneously generating oxygen by intelligent upconversion nanotherapeutics for enhanced photodynamic therapy. Biomaterials 251, 120088 (2020). https://doi.org/10.1016/j.biomaterials.2020.120088

31. X. Zhou, H.D. Li, C. Shi, F. Xu, Z. Zhang et al., An apnactivated nir photosensitizer for cancer photodynamic therapy and fluorescence imaging. Biomaterials 253, 120089 (2020). https://doi.org/10.1016/j.biomaterials.2020.120089 
32. M. Wang, M.Y. Chang, Q. Chen, D.M. Wang, C.X. Li et al., $\mathrm{Au}_{2}$ Pt-PEG-Ce6 nanoformulation with dual nanozyme activities for synergistic chemodynamic therapy/phototherapy. Biomaterials 252, 120093 (2020). https://doi.org/10.1016/j.bioma terials.2020.120093

33. C.H. Takimoto, M.P. Chao, C. Gibbs, M.A. McCamish, J. Liu et al., The macrophage "do not eat me' signal, cd47, is a clinically validated cancer immunotherapy target. Ann. Oncol. 30, 486-489 (2019). https://doi.org/10.1093/annonc/mdz006

34. X.J. Liu, Y. Pu, K. Cron, L.F. Deng, J. Kline et al., Cd47 blockade triggers t cell-mediated destruction of immunogenic tumors. Nat. Med. 21, 1209 (2015). https://doi.org/10.1038/ nm.3931

35. Q.J. Lv, L.L. Cheng, Y. Lu, X.G. Zhang, Y.Z. Wang et al., Thermosensitive exosome-liposome hybrid nanoparticlemediated chemoimmunotherapy for improved treatment of metastatic peritoneal cancer. Adv. Sci. 7, 2000515 (2020). https://doi.org/10.1002/Advs.202000515

36. J.W. Tian, L. Ding, H.J. Xu, Z. Shen, H.X. Ju et al., Cellspecific and ph-activatable rubyrin-loaded nanoparticles for highly selective near-infrared photodynamic therapy against cancer. J. Am. Chem. Soc. 135, 18850-18858 (2013). https:// doi.org/10.1021/ja408286k

37. J.J. Li, A. Dirisala, Z.S. Ge, Y.H. Wang, W. Yin et al., Therapeutic vesicular nanoreactors with tumor-specific activation and self-destruction for synergistic tumor ablation. Angew. Chem. Int. Ed. 56, 14025-14030 (2017). https://doi.org/10. 1002/anie.201706964

38. L.H. Fu, C. Qi, Y.R. Hu, J. Lin, P. Huang, Glucose oxidaseinstructed multimodal synergistic cancer therapy. Adv. Mater. 31, e1808325 (2019). https://doi.org/10.1002/adma.20180 8325

39. L.H. Fu, Y. Wan, C. Qi, J. He, C. Li et al., Nanocatalytic theranostics with glutathione depletion and enhanced reactive oxygen species generation for efficient cancer therapy. Adv. Mater. 33, e2006892 (2021). https://doi.org/10.1002/adma. 202006892

40. L.H. Fu, Y. Wan, C. Li, C. Qi, T. He et al., Biodegradable calcium phosphate nanotheranostics with tumor-specific activatable cascade catalytic reactions-augmented photodynamic therapy. Adv. Funct. Mater. 31, e2009848 (2021). https://doi. org/10.1002/adfm.202009848

41. X.G. Zhang, J.J. Tang, C. Li, Y. Lu, L.L. Cheng et al., A targeting black phosphorus nanoparticle based immune cells nano-regulator for photodynamic/photothermal and photoimmunotherapy. Bioact. Mater. 6, 472-489 (2021). https:// doi.org/10.1016/j.bioactmat.2020.08.024

42. W. Tao, X.Y. Ji, X.D. Xu, M.A. Islam, Z.J. Li et al., Antimonene quantum dots: Synthesis and application as near-infrared photothermal agents for effective cancer therapy. Angew. Chem. Int. Ed. 56, 11896-11900 (2017). https://doi.org/10. 1002/anie. 201703657

43. Z. Li, H. Zhang, J. Han, Y. Chen, H. Lin et al., Surface nanopore engineering of $2 \mathrm{~d}$ mxenes for targeted and synergistic multitherapies of hepatocellular carcinoma. Adv. Mater. 30, e1706981 (2018). https://doi.org/10.1002/adma.201706981
44. X. Han, J. Huang, H. Lin, Z. Wang, P. Li et al., 2d ultrathin mxene-based drug-delivery nanoplatform for synergistic photothermal ablation and chemotherapy of cancer. Adv. Healthcare Mater. 7, e1701394 (2018). https://doi.org/10.1002/adhm. 201701394

45. L. Rao, B. Cai, L.L. Bu, Q.Q. Liao, S.S. Guo et al., Microfluidic electroporation-facilitated synthesis of erythrocyte membrane-coated magnetic nanoparticles for enhanced imaging-guided cancer therapy. ACS Nano 11, 3496-3505 (2017). https://doi.org/10.1021/acsnano.7b00133

46. H. Cheng, J.Y. Zhu, S.Y. Li, J.Y. Zeng, Q. Lei et al., An O-2 self-sufficient biomimetic nanoplatform for highly specific and efficient photodynamic therapy. Adv. Funct. Mater. 26, 7847-7860 (2016). https://doi.org/10.1002/adfm.201603212

47. J.Y. Zhu, D.W. Zheng, M.K. Zhang, W.Y. Yu, W.X. Qiu et al., Preferential cancer cell self-recognition and tumor self-targeting by coating nanoparticles with homotypic cancer cell membranes. Nano Lett. 16, 5895-5901 (2016). https://doi.org/ 10.1021/acs.nanolett.6b02786

48. W.S. Chen, K. Zeng, H. Liu, J. Ouyang, L.Q. Wang et al., Cell membrane camouflaged hollow prussian blue nanoparticles for synergistic photothermal-/chemotherapy of cancer. Adv. Funct. Mater. 27, 1605795 (2017). https://doi.org/10.1002/ Adfm.201605795

49. J.A. Tang, D.L. Shen, T.G. Caranasos, Z.G. Wang, A.C. Vandergriff et al., Therapeutic microparticles functionalized with biomimetic cardiac stem cell membranes and secretome. Nat Commun (2017). https://doi.org/10.1038/Ncomms13724

50. Y.R. Zhang, J.Q. Luo, J.Y. Zhang, W.M. Miao, J.S. Wu et al., Nanoparticle-enabled dual modulation of phagocytic signals to improve macrophage-mediated cancer immunotherapy. Small 16, e2004240 (2020). https://doi.org/10.1002/smll. 202004240

51. X. Zhou, X. Liu, L. Huang, Macrophage-mediated tumor cell phagocytosis: Opportunity for nanomedicine intervention. Adv. Funct. Mater. 31, 2006220 (2021). https://doi.org/10. 1002/adfm.202006220

52. A. Ramesh, S. Kumar, A. Nguyen, A. Brouillard, A. Kulkarni, Lipid-based phagocytosis nanoenhancer for macrophage immunotherapy. Nanoscale 12, 1875-1885 (2020). https:// doi.org/10.1039/c9nr08670f

53. L. Cheng, X. Zhang, J. Tang, Q. Lv, J. Liu, Gene-engineered exosomes-thermosensitive liposomes hybrid nanovesicles by the blockade of cd47 signal for combined photothermal therapy and cancer immunotherapy. Biomaterials 275, 120964 (2021). https://doi.org/10.1016/j.biomaterials.2021.120964

54. X. Liu, Y. Liu, P.C. Zhang, X.D. Jin, X.G. Zheng et al., The synergistic radiosensitizing effect of tirapazamine-conjugated gold nanoparticles on human hepatoma HepG2 cells under X-ray irradiation. Int. J. Nanomed. 11, 3517-3530 (2016). https://doi.org/10.2147/Ijn.S105348

55. Z. Zhang, P. Oliver, J.R. Lancaster Jr., P.O. Schwarzenberger et al., Reactive oxygen species mediate tumor necrosis factor alpha-converting, enzyme-dependent ectodomain shedding induced by phorbol myristate acetate. FASEB J. 15, 303-305 (2001). https://doi.org/10.1096/fj.00-0371fje 